\title{
Business-Linkage Volatility Spillovers \\ Between US Industries
}

Linh Xuan Diep Nguyen ${ }^{\mathrm{a}}$, Simona Mateut ${ }^{\mathrm{b} *}$ and Thanaset Chevapatrakul ${ }^{\mathrm{b}}$

\begin{abstract}
We examine the volatility transmission across industries and its dependence on the inter-industry business linkages. Our analysis reveals significant cross-industry volatility spillovers, which are clearly associated with the strength of the trade relationship between industries. An industry that is more important to its trade partner - as measured by the shares of inputs or revenue - tends to have stronger volatility spillovers toward its partner and it is less affected by the volatility originating from its partner. Importantly, the strength of the business relationship appears highly relevant for shock spillovers in bad market conditions and is also confirmed at the portfolio level.
\end{abstract}

JEL classification: C30; E16; E44; G11; G12

Keywords: Asset pricing; Stock markets; Volatility spillovers; Multivariate GARCH; Input-Output linkages

\footnotetext{
* Corresponding address: Mateut: University of Nottingham, Business School, Jubilee Campus, Nottingham, NG8 1BB, UK. E-mail: simona.mateut @ nottingham.ac.uk. Telephone: 44-115-8468122. Fax: 44-115-8466667.

a School of Business, University of Leicester, University Road, Leicester, LE1 7RH, UK; Ixdn1@le.ac.uk

b University of Nottingham, Business School, Jubilee Campus, Nottingham, NG8 1BB, UK

Chevapatrakul: thanaset.chevapatrakul@nottingham.ac.uk
} 


\section{Introduction}

Industries in an economy are connected through an intricate network of transactions of goods and services, as output produced by an industry serves as input in the production processes of other industries. Via these interconnections, industry-specific shocks may propagate throughout the economy, possibly leading to aggregate fluctuations (Acemoglu et al., 2012). Intertwined with the real flows, the accompanying inter-industry financial flows may also create a propagation mechanism, whereby idiosyncratic financial shocks, and hence stock price fluctuations, transmit via the supplier-customer chain. In other words, the volatility of stock returns of an industry is likely to depend on the stock returns' volatility of its trade partner industries. This is the focus of our paper: how stock return volatility of each industry in the economy propagates across industries and how the degree of transmission can be explained by the input-output linkages.

Although evidence of return spillovers across assets, firms and industries is abundant in the finance literature, investigation of the transmission of volatility across industries has drawn relatively little attention. ${ }^{1}$ To date, only a handful of studies have examined volatility spillovers among industries within specific sectors such as energy and financials (among others, see Alli et al., 1994; Ewing et al., 2002; Elyasiani et al., 2007). ${ }^{2}$ To the best of our knowledge, our work is the first to investigate the volatility spillovers across all the industries of an economy and their association with the strength of the inter-industry trade relationships.

Our analysis proceeds in two stages. In the first stage, we use a bivariate GARCH model to measure the extent to which shocks and return volatility are transmitted within pairs of industries in a trading relationship. This part of our analysis resembles Elyasiani et al. (2007) but differs from theirs in two main respects. Firstly, Elyasiani et al. (2007) investigate the volatility transmission among three industries in the financial sector (i.e., banks, securities firms and life insurance companies) while we consider all economic sectors and calculate the volatility spillovers for all the pairs of industries in the US economy. This is done by estimating the bivariate GARCH models for a total of 2,080 distinct industry pairs. Secondly, we alter the GARCH specification in two important ways: we include the autoregressive term in the mean equations to account for the well-documented smoothing behavior of returns, and a shock

\footnotetext{
${ }^{1}$ A well-established body of literature shows evidence of volatility spillovers among international stock markets (Hamao et al., 1990; King and Wadhwani, 1990; Koutmos and Booth, 1995) or within specific geographic areas (Booth et al., 1997; Miyakoshi, 2003; Kohonen, 2013).

${ }^{2}$ Wang (2010) investigates the volatility transmission among 30 US industries but focuses on identifying leadinglagging industries without considering the underlying economic linkages between them.
} 
spillover term in the variance equations to allow for the separation of volatility spillovers into permanent and temporary components.

In the second stage of the analysis, we estimate cross-sectional models, linking the degree of volatility spillovers (the first-stage GARCH and ARCH parameter estimates) with the measures of economic relationship between industries, which are constructed from the US Input-Output (IO) accounts from the Bureau of Economic Analysis (BEA). The IO tables record all the dollar flows between all producers and purchasers in the entire US economy, aggregated at industry levels that best measure customer and supplier relations. Our models also include other industry-specific characteristics (such as size and concentration ratio) that are thought to affect the degree of return volatility spillovers across industries.

This part of our analysis relates to other studies in finance. ${ }^{3}$ Menzly and Ozbas (2010) use the supplier-customer relationship derived from the IO accounts in an asset pricing context. For each industry, they construct portfolios of the representative supplier (customer) industry, taking into account the industry's trade flows with all supplier (customer) industries. They find evidence indicating that returns on an industry can be explained by the lagged returns of its representative supplier and customer industries. Ahern (2013) finds that return spillovers depend on the closeness of the industries in the production network: an industry' returns have an immediate impact on the closely-related industries and a delayed (12-month lagged) effect on the distant-connected industries. ${ }^{4}$ In contrast to the studies mentioned above, we are the first to focus on spillovers in the second moment rather than the first moment.

As a preview of our main results, we find evidence of significant volatility spillovers between US industries: $83 \%$ of the industry pairs display significant volatility spillovers (either GARCH or ARCH). Importantly, our results from the second-stage analysis show that interindustry volatility spillovers indeed depend on the strength of the trading relationship between the two industries. Specifically, the stock returns' volatility of an industry with a prominent role (i.e., being a major customer or a major supplier) relative to its trading partner transmits strongly to its partner, while the partner's volatility has much less of an impact on the prominent industry's volatility. Our results also suggest that spillovers from external shocks are more strongly connected to business linkages than pure volatility spillovers between industries, pointing to the vulnerability of industries to external uncertainty.

\footnotetext{
${ }^{3}$ Ahern and Harford (2014) examine the impact of the supply-chain relationships on US merger activities.

${ }^{4}$ Aobdia et al. (2014) confirm the interdependence of returns between a "source industry" and its "linked industry" (i.e., a portfolio of its trading partner industries).
} 
We examine whether the relation between business linkages and volatility spillovers is influenced by the overall market conditions. To this end, we repeat our two-stage analysis on three separate samples: the pre-crisis period of 2005-2006, the crisis period of 2007-2008, and the bull-market period of 2009-2013. Our estimates reveal that shock spillovers and business linkages correlate strongly during the bad market conditions of the 2007-2008 financial crisis.

Having identified the link between volatility spillovers and the strength of the business linkages at the industry-pair level, we then investigate whether we observe volatility spillovers at trade-portfolio level. This investigation will reveal the aggregate spillovers between an industry and all of its customers / suppliers, and how the spillovers are influenced by the structure of an industry's supplier and customer profiles. Following Menzly and Ozbas (2010), we use the IO data to construct two portfolios of representative suppliers and representative customers for each US industry. We then conduct the first-stage bivariate volatility spillover analysis for each industry and its representative supplier and representative customer, respectively. Our results suggest significant volatility spillovers at the portfolio level for 61 out of 65 industries. In line with our results for the industry level, we confirm the link between the strength of the business relationship and volatility spillovers at the portfolio level.

Our findings remain qualitatively unchanged when we subject the empirical analysis to a battery of sensitivity checks. They are robust to the specification of the conditional correlation structure in the bivariate framework, to a trivariate GARCH setting, to alternative measures of the business linkage variables using either different annual IO data or the average values for the sample period. Furthermore, our main results remain unaltered when we conduct our twostage analysis on samples restricted to: (i) industry-pairs with substantial trade relationship, to acknowledge that certain pairs of industries trade relatively little with each other; (ii) nonfinancial industries, as the financial sector is expected to have stronger volatility spillovers to other industries in the economy.

Our paper relates to a strand of the economics literature which proves the importance of the input-output linkages in the comovement of sectors in the economy. For instance, Shea (2002) shows how fluctuation in the production of one industry is affected by shocks to all other industries, where the downstream (upstream) propagation of supply (demand) shocks depends on the strength of the cost (demand) linkages between industries. Gabaix (2011) demonstrates that aggregate fluctuation decays much more slowly in an economy with a fattailed firm-size distribution, contradicting the diversification argument put forward by Lucas (1977). Acemoglu et al. (2012) show that shocks to industries / sectors which act as main (direct or indirect) suppliers to a large number of industries in the economy propagate via the network 
of input-output connections and can result in aggregate fluctuations. ${ }^{5}$ Carvalho (2014) extends their framework to a dynamic multi-sector economy and demonstrates that the intersectoral network structure can account for a large fraction of the observed sectoral comovement and aggregate volatility of the US economy.

Our work contributes to research on how shocks (either industry-specific or general policy changes) transmit across industries and potentially trigger aggregate contagion, which enables policy-makers to take forward looking decisions in order to stem propagation of microeconomic fluctuation. Alongside policy-makers, business managers and stock investors can benefit from understanding how volatility transmits across industries. It is not uncommon for investors to maintain equity portfolios focusing on a group of related companies or on specific industries, such as energy or agriculture funds, among others. Since these portfolios may have significant weights in closely-linked industries, they may not be as well diversified as initially thought and are therefore more exposed to idiosyncratic risks. ${ }^{6}$ Indeed, Arouri et al. (2011) observe significant spillovers between oil and sector stock markets in US and Europe. They suggest that the inclusion of oil assets in a well-diversified portfolio of sector stocks leads to improved overall risk-adjusted performance and hedging effectiveness.

The rest of the paper is organized as follows. Section 2 presents our two-stage methodology and model. Section 3 describes the data and the construction of the businesslinkage measures. Section 4 reports our main empirical results. Section 5 examines the relation between business linkages and volatility spillovers in different market conditions. Section 6 takes a portfolio approach and investigates whether there are volatility spillovers between an industry and its representative supplier / customer. Section 7 collects several sensitivity tests. Section 8 concludes.

\section{Methodology and Model}

\subsection{A bivariate model for volatility spillovers}

We adopt a two-stage approach to investigate how the supplier-customer relationship between industries affects inter-industry volatility spillovers. We first estimate a bivariate GARCH model, commonly used in studies of risk and uncertainty spillovers, for every pair of industries.

\footnotetext{
5 The presence of dominant industries also increases the likelihood of large economic downturns if idiosyncratic microeconomic shocks exhibit some degree of tail risk in Acemoglu et al. (2017).

${ }^{6}$ Griffin and Karolyi (1998) point out that randomly assigning investments across industries within a country results in poor diversification as the reduction in the portfolio variance is significantly smaller than diversification across countries within the same industry. Their results may be due to cross-industry volatility spillovers which cause stock prices in closely-related industries to move in tandem thereby reducing the benefit of diversification.
} 
Following Campbell and Hamao (1992), we model the excess stock return of an industry as a function of the contemporaneous excess market return and other lagged exogenous variables. ${ }^{7}$ Similar to Elyasiani et al. (2007), an industry's excess stock return is assumed to be influenced by its trading partner's lagged excess return, while the exogenous variables include the change in the short-term interest rate, and the percentage change in the foreign exchange rate index. In addition, we also include the industry's own lagged return. The volatility of the excess return of an industry is specified as a function of the lagged values of its own and its partner's volatility and lagged shocks. For each industry pair we estimate the best-fitting constant conditional correlation $(\mathrm{CCC})$ bivariate $\operatorname{GARCH}(p, q)$ specified as follows: ${ }^{8}$

$$
\begin{aligned}
& R_{i, t}=\alpha_{10}+\alpha_{M 1} R_{M t}+\alpha_{F X 1} F X_{t-1}+\alpha_{\Delta R F 1} \Delta R F_{t-1}+\alpha_{11} R_{i, t-1}+\alpha_{12} R_{j, t-1}+\varepsilon_{i, t} \\
& h_{i i, t}=\beta_{10}+\sum_{k=1}^{p} \beta_{11 k} h_{i i, t-k}+\sum_{l=1}^{q} \gamma_{11 l} \varepsilon_{i, t-l}^{2}+\beta_{12} h_{j j, t-1}+\gamma_{12} \varepsilon_{j, t-1}^{2} \\
& R_{j, t}=\alpha_{20}+\alpha_{M 2} R_{M t}+\alpha_{F X 2} F X_{t-1}+\alpha_{\Delta R F 2} \Delta R F_{t-1}+\alpha_{22} R_{j, t-1}+\alpha_{21} R_{i, t-1}+\varepsilon_{j, t} \\
& h_{j j, t}=\beta_{20}+\sum_{k=1}^{p} \beta_{22 k} h_{j j, t-k}+\sum_{l=1}^{q} \gamma_{22 l} \varepsilon_{j, t-l}^{2}+\beta_{21} h_{i i, t-1}+\gamma_{21} \varepsilon_{i, t-1}^{2} \\
& \varepsilon_{i, t}\left|\Omega_{t-1} \sim N\left(0, h_{i i, t}\right) ; \varepsilon_{j, t}\right| \Omega_{t-1} \sim N\left(0, h_{j j, t}\right) \\
& h_{i j, t}=\rho_{i j} \sqrt{h_{i i, t} h_{j j, t}}, i \neq j
\end{aligned}
$$

where $R$ stands for the industry excess returns, $i$ and $j$ index industries $(i, j=1,2, \ldots, 65 ; i \neq$ $j$ ), and $t$ denotes the time period. $R_{M}, F X$, and $\Delta R F$ are the excess market return, the percentage change in the foreign exchange rate index, and the change in the short-term interest rate, respectively; $\varepsilon_{i}, \varepsilon_{j}$ are the error terms. The mean equations, Eqs. (1) and (3), describe the return spillovers between industries $i$ and $j$. Eqs. (2) and (4) are the volatility spillover equations, where $h_{i i}$ and $h_{j j}$ represent conditional volatility, $h_{i j}$ is the covariance of $\varepsilon_{i}$ and $\varepsilon_{j}$; and $\rho_{i j}$ is the time-invariant correlation coefficient between $i$ and $j$. Eq. (5) assumes that shocks at time $t$ are normally distributed conditional on the information realized at time $t-1$. Specifically, at time $t$, the residual vector $\boldsymbol{\varepsilon}_{t}=\left(\varepsilon_{i, t}, \varepsilon_{j, t}\right)$ follows $N\left(0, \mathbf{H}_{\mathrm{t}}\right)$ where

$$
\mathbf{H}_{\mathrm{t}}=\left[\begin{array}{ll}
h_{i i, t} & h_{i j, t} \\
h_{j i, t} & h_{j j, t}
\end{array}\right] .
$$

\footnotetext{
${ }^{7}$ In Campbell and Hamao (1992), the excess return of an asset is determined by the realization of price determining factors in the current period and the expected excess return of the asset in the previous period. Accordingly, the concurrent market return represents the factor realization, while the other exogenous variables are predictive variables and determine the expected excess returns.

${ }^{8}$ Section 4 provides details about the best-fitting GARCH model for each industry pair.
} 
We use the maximum likelihood method to estimate Eqs. (1)-(6) simultaneously. The parameter estimates are obtained by maximizing the following log likelihood function:

$$
\mathrm{LL}=\sum_{t=1}^{T}\left(-\frac{1}{2}\left[2 \ln (2 \pi)+\ln \left|\mathbf{H}_{\mathrm{t}}\right|+\boldsymbol{\varepsilon}_{t}^{\prime} \mathbf{H}_{t}^{-1} \boldsymbol{\varepsilon}_{t}\right]\right),
$$

where $T$ is the number of trading days in our sample.

Note that Eq. (6) allows for time-varying conditional volatility but restricts the correlation between the two industries to be time invariant. ${ }^{9}$ To ensure that the estimates of variance are non-negative and that the volatility process is stationary (i.e., the existence of constant long term volatility), we impose the following restrictions: all the $\beta$ and $\gamma$ coefficients in Eqs. (2) and (4) are positive for all $k$ and $l ; \sum_{k=1}^{p} \sum_{l=1}^{q}\left(\beta_{11 k}+\gamma_{11 l}\right)<1, \sum_{k=1}^{p} \sum_{l=1}^{q}\left(\beta_{22 k}+\right.$ $\left.\gamma_{22 l}\right)<1$; finally, the correlation coefficient satisfies $-1<\rho_{i j}<1$.

Our model is similar to Elyasiani et al. (2007) but differs from theirs in two respects. Firstly, we include the autoregressive terms in the mean equations, Eqs. (1) and (3), to account for the well-documented smoothing behavior of returns. Secondly, we include both the ARCH and the GARCH spillover effects in Eqs. (2) and (4) to allow for a decomposition of volatility spillovers into a permanent component (the GARCH spillover), and a transitory component due to temporary shocks (the ARCH spillover). The results of the first stage analysis shed light on the direction and strength of the ARCH and GARCH spillover effects between industries. ${ }^{10}$

\subsection{Cross-sectional analysis of the impact of business linkages on volatility spillovers}

To understand the effect of the business linkages on inter-industry volatility spillovers, in the second-stage we link the first-stage estimated volatility spillover coefficients to the measures of the strength of the inter-industry business relationship. As an illustration, the first-stage GARCH spillover coefficient $\beta_{21}$ quantifies the extent to which the lagged return volatility of industry $i$ affects the current volatility of its trading partner industry $j$, while the ARCH spillover coefficient $\gamma_{21}$ measures how the lagged shock (residual term) of industry $i$ 's returns affects the current volatility of industry $j$. In the second stage, we regress each of these

\footnotetext{
${ }^{9}$ Bollerslev (1990) shows that the constant correlation can ensure a positive semi-definite conditional variancecovariance matrix while many other specifications of multivariate GARCH model fail to do so. In section 7.1., we relax this assumption and allow for a dynamic conditional correlation. Our results remain unaffected.

${ }^{10}$ A fully comprehensive model would consider the dynamics of all other industries in the returns and volatility equations. However, the heavy parameterization in the multivariate GARCH framework renders such an approach intractable. We attempt to address this issue in two ways: 1) we adopt a portfolio approach in Section 6; 2) we replace $R_{M}$ in Eqs. (1) and (3) with the excess return of the portfolio of all other trading partners for each industry pair and estimate the GARCH model in a trivariate setting in section 7.2.
} 
coefficients on a set of variables measuring the strength of the business linkages between the two industries. Formally, we estimate the following cross-sectional regressions:

$$
\begin{aligned}
\text { GARCH Spillover }_{i j}= & \theta_{0}+\theta_{C-I n d} \text { CUST }_{j i}+\theta_{S-I n d} S U P P_{i j}+\theta_{C-P a r t} C U S T_{i j}+\theta_{S-P a r t} S U P P_{j i} \\
& +\theta_{\text {Ind }}^{\prime} \boldsymbol{x}_{i}+\theta_{\text {Part }}^{\prime} \boldsymbol{x}_{j}+u_{i j} \\
\text { ARCH Spillover }_{i j}= & \phi_{0}+\phi_{C-I n d} \text { CUST }_{j i}+\phi_{S-I n d} S U P P_{i j}+\phi_{C-P a r t} C U S T_{i j}+\phi_{S-P a r t} S U P P_{j i} \\
& +\phi_{\text {Ind }}^{\prime} \boldsymbol{x}_{i}+\phi_{\text {Part }}^{\prime} \boldsymbol{x}_{j}+v_{i j}
\end{aligned}
$$

where GARCH spillover $_{i j}$ and ARCH spillover $_{i j}$ are, respectively, the $\beta_{21}$ and $\gamma_{21}$ coefficients estimated in the first stage. The parameters measure the GARCH and the ARCH spillover effects from industry $i$ to industry $j$, respectively. $C U S T_{i j}, S U P P_{i j}, C U S T_{j i}$, and $S U P P_{j i}$ are the trading relationship variables. Specifically, $S U P P_{i j}$ shows the supplier role of industry $i$ to its partner industry $j$, while $C U S T_{i j}$ shows the customer role of the partner industry $j$ to industry $i$. $S U P P_{j i}$ and $C U S T_{j i}$ are defined similarly. The construction of these variables will be explained in the data section below. The coefficients associated with these variables determine how the strength of the trading relationship (the industry's customer and supplier roles relative to its partner, and vice versa) influences the spillover effects between the industries. Finally, $\boldsymbol{x}_{i}=\left(\text { Size }_{i}, C R_{i}\right)^{\prime}$ and $\boldsymbol{x}_{j}=\left(\text { Size }_{j}, C R_{j}\right)^{\prime}$ control for industry characteristics such as the number of firms in the industry (Size) and the industry concentration ratio $(C R)$.

\section{Data and summary statistics}

\subsection{Industry returns and macroeconomic variables}

The daily stock return data used in the first-stage estimation are obtained from the CRSP database. Stocks in the CRSP database are matched to those in the IO Benchmark Survey by their NAICS codes. We use daily return data for all the stocks on four major stock markets in the US, including NYSE, Nasdaq, Amex and Arca. Daily industry returns are computed as the sum of value-weighted returns of all the stocks in the industry where the beginning-of-the-day market capitalization of each stock is used as the weight. We use the yield on the 3-month US Treasury bills as a proxy for the risk-free rate. The excess industry return is calculated as the difference between the industry return and the risk-free rate. In the same way, the excess market returns are computed as the difference between market returns, which are proxied by returns on the CRSP value weighted index, and the risk-free rate. Our sample spans a period of 9 years beginning from 1 January 2005 (when NAICS codes become available on CRSP) to 31 December 2013. 
Data on the 3-month T-bill interest rates and the trade weighted USD indexes against a broad group of major US trading partners are obtained from the Federal Reserve Bank of St. Louis (FRED) database. According to the Augmented Dickey-Fuller (ADF) test results, the stock return series in our model are found to be stationary but the interest rate and the foreign exchange index series follow an I(1) process. Therefore, our models include the change in the interest rate and the percentage change in the foreign exchange rate index, which are stationary.

\subsection{Input-Output accounts}

We measure the extent to which industries are linked to one another using information from the Input-Output (IO) accounts provided by the Bureau of Economic Analysis (BEA). These accounts document the value of commodities (goods and services) produced and transacted among industries. Details on the amount of flows between US industries are recorded at three levels of aggregation: the sector level (15 sectors), the summary industry level (71 industries), and the detailed industry level (389 industries). The IO tables are updated roughly every five years (years ending in 2 and 7) with each update coinciding with the Economic Census. For non-benchmark years between updates, BEA provides estimated tables.

The annual IO accounts consist of two main tables: the Make and the Use tables. The Make table gives the value of each commodity produced by industries. It is worth noting that the same commodity may be produced by more than one industry. Moreover, while an industry predominantly produces one commodity, it may also produce other commodities. Each row in the Make table shows the industry while commodities are presented across different columns. Thus, the sum of all entries in a row gives the total output in that industry, which we denote by OUTPUT $_{i}$. Adding all the entries in a column gives the total output of a commodity produced by all the industries. The Use table reports the value of each commodity purchased as input by each industry (or consumed by final users). Each commodity is recorded in a row, while the columns report the industries. Therefore, summing all entries in a row gives total commodity output, while adding up all commodity entries in a column gives the total input value in an industry, denoted by INPUT . Total industry output, presented in the last row of the Use table, is the total industry input value plus the total value added. Using the raw data provided by both tables, we calculate the industry linkage variables capturing the strength of the relationship between pairs of industries.

We follow the methodology proposed by Ahern and Harford (2014) and Becker and Thomas (2011) to construct the CUST and SUPP matrices showing the roles of the industries 
as customers and suppliers with respect to each other. First, we construct the subordinate SHARE matrix, which shows each industry's share in the total supply of each commodity in the economy. The elements in the SHARE matrix are calculated using information from the Make table. Specifically, the element in row $i$, column $c$, denoted $S H A R E_{i c}$, is calculated as:

$$
\text { SHARE }_{i c}=\frac{\text { Make }_{i c}}{\text { Total Supplyc }_{c}}
$$

where $i$ and $c$ index industry and commodity, respectively. $M a k e_{i c}$ is the value of commodity $c$ produced by industry $i$ (element in row $i$, column $c$ of the Make table). Total Supply $y_{c}$ is the total supply of commodity $c$, which includes the total output of commodity $c$ produced by all the industries (the sum of all entries in the commodity $c$ column in the Make table) plus other components such as imports or changes in inventories.

Next, we calculate the REVSHARE matrix, which shows the value of all commodities that customer industries purchase from their supplier industries. Thus, the element in row $i$, column $j$ of this matrix, REVSHARE $E_{i j}$, gives the total value of all commodities industry $j$ purchases from industry $i$. Formally, it is given by:

$$
\operatorname{REVSHARE}_{i j}=\sum_{c=1}^{C}\left(\operatorname{SHARE}_{i c} \times U s e_{c j}\right)
$$

where $S H A R E_{i c}$ is the percentage of commodity c produced by industry $i$ (element in row $i$, column $c$ of the SHARE matrix) and $U s e_{c j}$ (row $c$, column $j$ element in the Use table) shows the value of commodity $c$ used in the production of industry $j .{ }^{11}$

Finally, we construct the CUST and SUPP matrices. The CUST matrix records the percentages of an industry's sales which are purchased by each of its customers while the SUPP matrix records the percentages of input which an industry purchases from each of its suppliers. As an example, consider the pair of industries $i$ and $j$. The elements in row $i$, column $j$ in the CUST matrix, denoted by $C U S T_{i j}$, and in the $S U P P$ matrix, denoted by $S U P P_{i j}$, are defined as follows:

$$
\operatorname{CUST}_{i j}=\frac{\text { REVSHARE }_{i j}}{\text { OUTPUT }_{i}}
$$

\footnotetext{
${ }^{11}$ The calculations rely on the assumption that market shares are constant for every use of commodity. In other words, if industry $i$ accounts for $80 \%$ of the total supply of commodity $c$ (i.e., $S H A R E_{i c}=0.8$ ), then industry $j$ purchases $80 \%$ of its commodity $c$ input from industry $i$.
} 


$$
S U P P_{i j}=\frac{R E V S H A R E_{i j}}{I N P U T_{j}}
$$

where $C U S T_{i j}$ is the proportion of industry $i$ 's revenue generated by industry $j$. It is calculated by dividing $R E V S H A R E_{i j}$, the total value of all commodities which industry $j$ purchases from industry $i$, by the total output value of industry $i$ (OUTPUT $i$ in the Make table). SUPP $i j$, the proportion of industry $j$ 's total input purchased from industry $i$, is calculated by dividing $R E V S H A R E_{i j}$ by the total input value of industry $j\left(I N P U T_{j}\right) .{ }^{12}$ Therefore, for the pair of industries $i$ and $j$, we obtain a total of four relationship variables, namely $C U S T_{i j}, S U P P_{i j}$, $C U S T_{j i}$, and $S U P P_{j i}$, which show the customer role of $j$ to $i$, the supplier role of $i$ to $j$, the customer role of $i$ to $j$, and the supplier role of $j$ to $i$, respectively. ${ }^{13}$

To fix ideas, Fig 1 depicts the business linkages of the primary metals (PM) industry. Panel A lists some of its industry trade partners. The top (bottom) row ranks PM's suppliers (customers) in descending order based on the percentage of supplier (customer) role. Panel B tabulates the values of the relationship variables for PM (industry $i$ ) and its trade partner (industry $j$ ) Mining, except oil and gas (MNG). The top row of Panel A lists MNG as PM's second largest supplier, accounting for $8.35 \%$ of PM's input value ( $\left.S U P P_{j i}\right)$. PM's purchases contribute $18.01 \%$ of MNG's revenue $\left(C U S T_{j i}\right)$. The bottom row of Panel A reveals a weaker trade relationship between PM as a supplier and MNG as a customer: PM accounts for $0.17 \%$ of MNG's input value $\left(S U P P_{i j}\right)$; MNG is PM's $22^{\text {nd }}$ largest customer, contributing to $0.71 \%$ of PM's revenue $\left(C U S T_{i j}\right)$.

The four relationship variables $\left(C U S T_{i j}, S U P P_{i j}, C U S T_{j i}\right.$, and $\left.S U P P_{j i}\right)$ will be used in the second-stage cross-sectional analysis which examines whether the strength of the trading relationship influences the spillover effects between industries.

\subsection{Industry characteristics}

To account for the impact of industry-specific characteristics on the volatility spillovers between industries, our second-stage regressions control for industry size and concentration ratio. Industry size is measured as the number of firms in an industry. The data is obtained from the Statistics of US Businesses (SUSB) on a yearly basis. Industry concentration is measured

\footnotetext{
${ }^{12}$ Although there is no Labor industry in the Make table, an artificial Labor industry is created in the Use table as an input for production (namely employee compensation), to ensure that input values are accurately calculated. This industry is not used in our final sample. Ahern and Harford (2014) use a similar approach.

${ }^{13}$ Appendix A provides snapshots of the 2007 IO accounts (the Make and Use tables) and the constructed tables.
} 
as the percentage of the total industry revenue accounted for by the eight largest firms in the industry. The concentration ratios are reported in the Economic Censuses issued by the US Census Bureau every five years, the same years when the IO benchmark tables are published. A similar approach has been employed by Ahern (2013) who controls for industry size and concentration ratio in modelling stock returns and Kelly et al. (2013) who show that the concentration of the customer portfolio of firms can affect the firms' volatility.

\subsection{Summary statistics}

We build our industry-level sample starting from the summary IO tables of 71 industries and 73 commodities. We drop five industries in the Government sector without NAICS codes and combine 2 industries with the same NAICS code. Our final sample includes 65 industries, for which we can construct 2,080 possible trading pairs. This means that in our first-stage approach we estimate 2,080 bivariate GARCH models - one for each industry pair.

Table 1 presents descriptive statistics of our data. Panel 1 reports summary statistics for the macroeconomic variables used in our first stage regression (return statistics of the 65 industries available upon request). Panel 2 presents descriptive statistics of the industry-level controls used in the cross-sectional regressions. Information on industry size is available only for 63 industries in our sample. Industry size ranges from as low as 241 firms in the smallest industry (Pipeline transportation) to nearly 800,000 firms in the largest industry (Construction). Concentration ratio data is available for 56 industries. The eight-firm concentration ratio ranges from 4 percent in the most competitive industry (Other services, except government) to 85 percent in the most concentrated industry (General merchandise stores).

Table 2 gives the statistics of the CUST and SUPP variables calculated from the IO tables for each year over the period 2005-2013. We report the mean, the median, the bottom and the top $5^{\text {th }}$ percentiles of the distribution of the values. Proportions (frequency percentages) of different CUST and SUPP value ranges are also reported. The numbers in this table show that most industry pairs have a weak trading relationship. Consistent across the sample period, over 80 percent of the linkage variables are below 1 percent. The fraction of weak linkages as measured by CUST is slightly larger than that for SUPP (87\% relative to $81 \%$ ), which implies that industries tend to have slightly more diversified customers than suppliers. 
In the analysis that follows we use the trading relationship variables based on the 2007 benchmark IO account. ${ }^{14}$ Using the data in the CUST matrix, each industry is assigned the role of either a main or a small customer of its trading partner. Similarly, based on data in the SUPP matrix, each industry is classified as either a main or a small supplier of its trading partner. Overall, there are 10 possible combinations that characterize the importance of the supplier and customer roles in an industry pair. As discussed above, over $80 \%$ of the values of the relationship measures are less than 1\%. Consistent with Ahern and Harford (2014), we choose the $1 \%$ level as the smallest cut-off to classify an industry as a main or a small trading partner.

Table 3 gives a snapshot of the structure of the linkages between industries at different cut-off levels. The columns labelled 1 to 10 report the numbers of industry pairs in each combination group at each corresponding threshold. According to the values in the column corresponding to the $1 \%$ threshold, the majority of the industry pairs have weak business linkages, i.e., 1,328 pairs have values for both CUST and SUPP below 1\%. When industries are finely classified, each industry is likely to have only a few main suppliers and customers while its trade flows with most industries are relatively low. The remaining 752 industry pairs are closely linked, i.e., at least one of the industries is a main customer or a main supplier.

Panel 2 provides more details for the closely-linked industry pairs. 589 pairs have a one-directional relationship in that one industry is a main supplier or a main customer. A total of 644 pairs have at least one main supplier while 457 pairs have at least one main customer. In fewer cases, an industry could serve as both major customer and supplier (162 pairs), both industries are major customers (45 pairs), or both industries are major suppliers (81 pairs). The other columns in Table 3 report the number of pairs for each combination of linkages at the different thresholds. Clearly, for a given classification of supplier and customer relationship, the number of close linkages decreases as the threshold increases.

\section{Empirical results}

\subsection{Volatility spillovers between supplier-customer industries}

A series of preliminary checks are conducted before we begin the volatility spillover analysis. Firstly, we confirm the existence of conditional heteroscedasticity in the return series as the minimum value of the Engle (1982)'s Lagrange Multiplier (LM) test statistics including one

\footnotetext{
${ }^{14}$ In Section 7.3, we show that using instead the 2012 benchmark table, the estimated tables for each year, or the average values calculated over the sample period leaves our second-stage results unaltered.
} 
lag for all return series is 7.6, which is larger than the critical value of 6.6 at the $1 \%$ significance level. Hence, an ARCH-type model is appropriate for our analysis.

Next, we fit the following four GARCH specifications to the daily data for the 2,080 industry pairs: $\operatorname{GARCH}(1,1), \operatorname{GARCH}(2,1), \operatorname{GARCH}(1,2)$, and $\operatorname{GARCH}(2,2)$. We use the Akaike information criterion (AIC) to identify the best-fitting specification for each industry pair. We can report that $\operatorname{GARCH}(2,1)$ is found to be the best-fitting model for 1,105 industry pairs, while the numbers of best-fitting $\operatorname{GARCH}(1,1), \operatorname{GARCH}(1,2)$, and $\operatorname{GARCH}(2,2)$ are 415, 101, and 459, respectively. Finally, the Ljung-Box (1978) test results suggest that the residuals and their squared terms are white noise in about $73 \%$ and $90 \%$ of the cases, respectively. ${ }^{15}$

Note that the GARCH and the ARCH coefficients for industry pair $i j$ are equal in value to those obtained for industry pair $j i$ but in the reverse order. ${ }^{16}$ Purely for the purpose of presenting the first-stage estimates, we choose to report the set in which $i$ is the industry with the higher REVSHARE selling to the other industry in the industry pair $i j$. By doing this, industry $i$ is more likely to be the upstream industry in the pair, but this is not always the case. For the rest of the paper, the role of the industry as a supplier or a customer of its partner industry is determined as specified in the methodology section.

Table 4 reports the summary statistics of the estimates obtained from the bivariate volatility spillover models for each of the 2,080 industry pairs. The return spillover coefficients $\left(\alpha_{12}, \alpha_{21}\right)$ are statistically significant in around $25 \%$ of the cases. There is stronger evidence of volatility spillovers: the GARCH spillover coefficient (either $\beta_{12}$ or $\beta_{21}$ or both) is statistically significant for $47.3 \%$ industry pairs ( $\beta_{12}$ for 449 pairs and $\beta_{21}$ for 607 pairs) while the ARCH spillover is significant for $64.5 \%$ industry pairs $\left(\gamma_{12}\right.$ for 796 pairs and $\gamma_{21}$ for 891 pairs). Overall, we observe significant volatility spillovers, either GARCH, ARCH or both, for $83 \%$ of the industry pairs. This suggests strong volatility linkages between the US industries, which is consistent with Wang (2010).

Close inspection of the volatility spillover coefficients $\left(\beta_{12}, \beta_{21}, \gamma_{12}\right.$, and $\left.\gamma_{21}\right)$ reveals that the industry pairs with the highest values are: (i) Wholesale trade and Warehousing and storage; (ii) Miscellaneous manufacturing and Social assistance; (iii) Wholesale trade and

\footnotetext{
${ }^{15}$ Using the multivariate Li and McLeod (1981) test instead, we fail to reject the null hypothesis that the residuals (squared residuals) are white noise in approximately $63 \%(86 \%)$ of the cases.

${ }^{16}$ For example, consider industry 1 (Farms) and industry 6 (Utilities) in the IO tables. Swapping the order of industries in the pair leads to two sets of the first-stage regression parameters: $\operatorname{set}_{16}$ and set $_{61}$, where set $_{16}$ is obtained when Farms is industry $i$ and Utilities is industry $j$, and vice versa. Obviously, the coefficients showing GARCH and ARCH spillover from Farms to Utilities are identical in both sets, i.e., $\beta_{21}$ and $\gamma_{21}$ in set $t_{16}$ equal $\beta_{12}$ and $\gamma_{12}$ in set $t_{61}$, respectively.
} 
Legal service; and (iv) Wholesale trade and Social assistance, respectively. The volatility of the Wholesale trade industry appears to be strongly linked to that of a number of other industries in the economy. Considering the nature of this industry, the result is not unexpected.

Most of the coefficients associated with the industry and its partner's lagged GARCH and ARCH terms are statistically significant. The ARCH term at lag 1 is significant for $97 \%$ of the industry pairs, while the GARCH term at lag 1 is significant for $64 \%$ of the pairs. The GARCH and ARCH terms at lag 2 are also significant in $74 \%$ and $63 \%$ of the best-fitting models, respectively. This justifies the use of a GARCH type model in our study.

Turning to the impact of the controls on industry returns, we find that the market return has a marked influence on all industry returns, with the coefficient value ranging from 0.558 to 1.646. The interest rate is found to affect a larger proportion of industries (34\%) compared to the foreign exchange rate index (13\%). This is not surprising since interest rates commonly affect most industries in the economy while foreign exchange rates tend to impact mainly the industries which extensively engage in international trade.

\subsection{The impact of business linkages on inter-industry volatility spillovers}

The first-stage results discussed in the previous section imply significant volatility and shock spillovers between US industries. We now investigate how the inter-industry spillovers are influenced by the business linkages between industries. ${ }^{17}$ To this end, our second-stage cross sectional models link the volatility spillover coefficient estimates with the business relationship variables (and other industry characteristics). For each industry pair $i j$ we obtain two spillover coefficients - from $i$ to $j$ and from $j$ to $i$ - for each spillover type (GARCH and ARCH). Consequently, from the 2,080 industry pairs we obtain 4,160 cross-section observations. ${ }^{18}$

As our dependent variables result from a first stage estimation, simple OLS regressions could produce inconsistent standard error estimates (Lewis and Linzer, 2005). To account for this, we resort to estimating and reporting bootstrapped standard errors. Specifically, we construct 1,000 bootstrap samples from the original sample by randomly drawing observations with replacement. We estimate the values of the coefficients for each bootstrap sample and construct their bootstrap distributions. The bootstrap standard errors are obtained from the

\footnotetext{
${ }^{17}$ We first check that volatilities are at similar levels: the mean volatility of the 65 industry portfolios is 1.795 and the standard deviation is 0.438 . On average, the ratio of the volatilities of two industries in a pair is 1.063 , and the standard deviation 0.380. In a separate unreported exercise, we include the ratio of the volatilities of the two industries in a pair in the second-stage regression and obtain qualitatively similar results. This confirms the rationale and robustness of our second-stage investigation.

18 The number of observations drops to 3,906 and 3,080, respectively, when we control for industry size (data available for 63 industries only) and concentration ratio (available for 56 industries).
} 
bootstrap distribution. ${ }^{19}$ Alternatively, we estimate robust standard errors (see Lewis and Linzer, 2005; Weiß et al., 2014) and obtain qualitatively similar results (unreported). Since the robust standard errors are smaller than the bootstrapped ones, the results we present are more conservative (i.e. robust standard errors would imply even stronger statistical significance).

Table 5 reports the second-stage cross-sectional estimates. We observe that when an industry is relatively more important to its partner, its volatility affects its partner's more strongly while it is less affected by the volatility of its partner. The signs of all the coefficients on the business linkage variables are consistent with this pattern. Specifically, the GARCH and ARCH spillovers from an industry to its partner are positively related to its customer and supplier roles with respect to its trading partner. As industry $i$ gains a more important role among all customers $\left(C U S T_{j i}\right)$ and all suppliers $\left(S U P P_{i j}\right)$ of its trading partner $j$, there are stronger volatility spillovers from industry $i$ to its partner industry $j$. At the same time, the larger the trading partner's role among all customers $\left(C U S T_{i j}\right)$ and all suppliers $\left(S U P P_{j i}\right)$ of industry $i$, the less likely it is that industry $i$ 's volatility is transmitted to its partner's. This pattern points to a positive (negative) relation between the volatility spillover's outdegree (indegree) and the strength of the trade linkages between industries. Our findings suggest that the extent of domination of an industry - as measured by the trade flows - explains the strength of volatility transmissions to its trading partners, and are consistent with Gabaix (2011), Acemoglu et al. (2012), and Carvalho (2014).

Based on the significance level of these coefficients, we can further infer that the interindustry linkages tend to have a stronger impact on the ARCH than on the GARCH spillovers. The business linkages seem to significantly affect GARCH spillovers only in the defensive direction, i.e. when the importance of an industry to its partner increases (as the values of its $C U S T_{i j}$ and $S U P P_{j i}$ with respect to its partner increase), the industry is less affected by its partner. Since the GARCH terms measure persistent components in volatility, while the ARCH terms represent components of volatility that are due to short-term shocks, our results suggest that, compared to pure volatility spillovers, shocks are more easily transmitted between industries and are also more affected by the strength of the industry linkages. These findings are not unexpected since external shocks, by their very nature, are harder to predict and prevent. Industries are therefore likely to be more vulnerable to them.

Other industry characteristics, such as size and concentration, are also found to have an impact on the inter-industry volatility spillovers. The negative and statistically significant

\footnotetext{
${ }^{19}$ See also Dale-Olsen (2012) for the use of bootstrapped standard errors to account for generated regressand.
} 
coefficients associated with the size of the trading partner indicate that a larger partner industry is less affected by the volatility spillover from the examined industry. This is not surprising since an industry with a large number of firms tends to have more trading partners (at both firm and industry level). Diversification of trade partners helps an industry better protect itself from volatility transmitted from its partner. Similarly, a more concentrated industry, in which a few companies dominate the product market, tends to be less sensitive to the volatility spillover from its trading partner. This is evidenced by the negative coefficient associated with the concentration ratio in the trading partner industry. Importantly, controlling for industry size and concentration ratio further strengthens our results regarding the importance of business linkages on inter-industry volatility spillovers.

\section{Different market conditions}

Our sample period includes the 2007-2008 Financial Crisis and the strong bull market observed during 2009-2013. In this section, we conduct the two-stage analysis on separate sub-samples corresponding to the three different market conditions. ${ }^{20}$ In other words, we estimate the firststage bivariate GARCH model using daily data for the pre-crisis period of 2005-2006, the crisis period of 2007-2008, and the bull market period of 2009-2013, respectively.

The second-stage results of these cross-sectional investigations are reported in Table 6. Relative to the results for the whole sample period presented in Table 5, all coefficients preserve their signs and most parameters maintain their statistical significance across samples, confirming the impact of business linkages on volatility spillovers. Importantly, however, Panel 3 reveals that the strength of the business linkages played a more important role for spillovers across industries during the financial crisis period. In terms of GARCH spillovers, important suppliers are likely to transmit their volatility to their customers during the 20072008 period. At the same time, the ability of an industry to protect itself from volatility spillovers from its partners depends on its supplier and customer role to its partners. An industry's volatility is less likely to be transmitted to its important customers and even more so to its main suppliers. Overall, these results suggest a stronger impact of business linkages on the downward transmission of GARCH spillovers during the financial crisis.

Business linkages tend to become highly relevant for shock (ARCH) spillovers in bad market conditions. Comparing the coefficient values in columns 5-8 across the three panels,

\footnotetext{
${ }^{20}$ In a separate exercise, the first-stage Eqs. (1) and (3) include a dummy variable to control for the impact of the 2007-2008 financial crisis when we use the whole sample period in estimation. The second-stage analysis proceeds as before. The results in Appendix B are qualitatively similar to our earlier findings.
} 
the impact of business linkages on shock spillover surges during the crisis period and subsequently declines after the crisis. Business linkages appear to have a stronger impact on shock spillovers when shocks are more prevalent. This would be expected since industries with higher trade flows are likely to have more influence over their partners, and at the same time, they can better protect themselves from their partners' volatility during bad times.

The weaker impact of business linkages on volatility spillover in the post-crisis sample might be due to the more stringent risk management framework employed by the US firms in the aftermath of the financial crisis. Businesses and industries which were affected by the sharp downturn during the crisis period may have implemented strategic measures to isolate themselves from the effect of external shocks spilled over from their trade partners.

\section{Volatility spillovers between industries and their representative trading partners}

Our analysis so far has revealed the link between inter-industry volatility spillovers and the strength of the trading relationship between industries. We now investigate whether spillovers exist at the portfolio level as well. Following Menzly and Ozbas (2010), we construct two portfolios for each industry to mark its representative supplier and representative customer industry. Specifically, industry $i$ 's representative supplier is a weighted-portfolio consisting of all the industries selling goods or services to industry $i$. Each supplier receives a weight based on its share in total industry $i$ 's inputs. ${ }^{21}$ The weights are calculated from the elements in the column corresponding to industry $i$ in the SUPP matrix. The representative customer is constructed in a similar way using elements in the CUST table.

For each industry, two separate bivariate volatility spillover models are estimated one with its representative supplier and one with its representative customer. ${ }^{22}$ Similar to our analysis at the industry-pair level, for each bivariate volatility model, we use the Akaike information criterion (AIC) to choose the best-fitting GARCH model among the following specifications: $\operatorname{GARCH}(1,1), \operatorname{GARCH}(1,2), \operatorname{GARCH}(2,1)$, and $\operatorname{GARCH}(2,2)$.

Table 7 presents the results for the portfolio analysis for the 65 industries in our sample. Panel 1 reports descriptive statistics for the estimates of volatility spillover between an industry and its representative supplier, while Panel 2 shows the statistics regarding the representative

\footnotetext{
${ }^{21}$ Although firms supply some amount of goods to other firms within the same industry, we exclude an industry from the list of its suppliers (customers) when we calculate its representative supplier (customer) industry.

${ }^{22}$ We focus on the spillovers caused by direct business linkages and disregard any indirect spillovers between an industry's representative supplier and its representative customer. Even if such indirect spillovers exist, there is no economic rationale for further investigation; these linkages are spurious since the representative supplier and customer industries are constructed from the same pool of industries with different weighting schemes.
} 
customer. Panel 3 groups this data to focus on the direction of the spillovers. We observe significant volatility spillovers between industries and their representative trading partners. Most industries (54 out of 65) are affected by their representative suppliers and/or customers and nearly two thirds of the industries (40 out of 65) influence their representative trading partners. The lower part of Panel 3 distinguishes downstream and upstream spillovers. While volatility appears to transmit downstream (supplier $\rightarrow$ industry and industry $\rightarrow$ customer) equally as likely as upstream (industry $\rightarrow$ supplier and customer $\rightarrow$ industry), shock spillovers are more likely to occur downward rather than upward along the supply chain according to the respective numbers of significant ARCH coefficients.

Panel 4 describes all the possible combinations of volatility spillovers between an industry $(\mathrm{I})$, its representative supplier $(\mathrm{S})$ and customer $(\mathrm{C})$. It reports the number of significant estimates of volatility spillovers, either from lagged volatility or from lagged shocks, for each of the 15 possible combinations. Arrows $(\rightarrow$ or $\leftarrow$ ) indicate the direction of the spillover, where “↔” means bi-directional volatility spillover and "..." indicates no spillovers. For example, the first row $(\mathrm{S} \ldots \mathrm{I} \rightarrow \mathrm{C}$ ) indicates volatility spillover only from industry I to its representative customer C. There is evidence of significant spillovers from / to their representative trading partners for 61 out of 65 industries. Only 4 industries - namely Construction, Food services and drinking places, Miscellaneous professional, scientific, and technical services, and Legal services - display no volatility spillovers from / to their representative suppliers and customers. These industries trade mostly with personal consumers rather than with other industries. While the first three are among the industries with the largest share of output accounted by personal consumption, Legal services is one of the top labor-intensive industries.

We now further scrutinize the determinants of the volatility spillovers from the industry's representative trading partners shown in Panel 3. We define a binary variable SuppInd equal to 1 when we observe significant volatility spillovers from the representative supplier to the industry, 0 otherwise. CustInd is defined similarly regarding spillovers from the representative customer to the industry. As in the industry pairwise analysis, we look at the relation between spillovers to the industry and the strength of the trading relationship at portfolio level. To this end, we calculate the Herfindahl-Hirschman index (HHI) of the two portfolios as the sum of the squared weights used in constructing the portfolios. Specifically, the HHI of the supplier portfolio is the sum of each industry's squared share in total industry $i$ 's 
inputs. The concentration index of the customer portfolio is calculated similarly using elements in the CUST table.

We estimate simple probit models and report the marginal effects in Table 8 . These estimates show that volatility spillovers from the representative supplier are negatively related with the suppliers' degree of concentration. This means that an industry is likely to be affected by the volatility of its suppliers the more diversified its supplier portfolio is. At first glance, this finding might seem to come at odds with our previous results that smaller suppliers are less likely to transmit their volatility over to their partner industries. At the supplier portfolio level we need to account for each supplier's contribution to an industry's total inputs as well as for the possible correlation between shocks affecting individual suppliers. It may be possible, for instance, that we find no evidence of volatility spillovers from individual suppliers to an industry in the pairwise analysis, but we find spillovers from the supplier portfolio if the shocks to individual suppliers are positively correlated. Calculating, therefore, the volatility of the supplier portfolio considers both shocks to individual suppliers and the correlation among these shocks. Our results are thus consistent with positively correlated shocks to individual suppliers in the portfolio.

The estimates in column 3 reveal a weak positive relationship between spillovers from the representative customer and the concentration of the customer portfolio. Volatility seems to be transmitted upward the production chain the more concentrated the customer portfolio is. Finally, similar to our previous results for pairs of industries, the estimates in columns 2 and 4 stress that industry size and concentration ratio matter. Smaller industries (in terms of number of firms) are more likely to suffer from shocks transmitted from their suppliers and customers. A higher industry concentration ratio, however, helps reduce volatility transmission from the supplier portfolio (column 2).

Overall, the results at the portfolio level are in line with those considering industry pairs and highlight the importance of the strength of the business relationship in the transmission of volatility across industries.

\section{Sensitivity analysis}

This section reports several robustness checks. The first two exercises employ two alternative GARCH models while the last three analyses test sensitivity to the choice of IO matrices, the exclusion of the financial industries or of the industries with low trade flows from the sample. As discussed below, all these empirical results confirm the strong link between the strength of the business relationship and cross-industry volatility spillovers. 


\subsection{Dynamic conditional correlation bivariate GARCH model}

The bivariate GARCH ( $p, q)$ model shown in Eqs. (1) - (6) assumes that the correlation is time invariant. In what follows, we relax this assumption by modelling the conditional volatility using a dynamic conditional correlation (DCC) GARCH. In an approach similar to Bali and Engle (2010), we substitute Eq. (6) with Eq. (14) below

$$
h_{i j, t}=\rho_{i j, t} \sqrt{h_{i i, t} h_{j j, t}}, i \neq j
$$

to allow for time-varying conditional correlation. The dynamic conditional correlation coefficients $\rho_{i j, t}$ are given by:

$$
\rho_{i j, t}=\frac{q_{i j, t}}{\sqrt{q_{i i, t} q_{j j, t}}}
$$

where

$$
q_{i j, t}=\overline{\rho_{l \jmath}}+\omega_{1}\left(u_{i, t-1} u_{j, t-1}-\overline{\rho_{l \jmath}}\right)+\omega_{2}\left(q_{i j, t-1}-\overline{\rho_{l \jmath}}\right)
$$

where $\omega_{1}$ and $\omega_{2}$ adjust the conditional correlation coefficient based on the recent realization of the error terms and the correlation process. The constant term $\overline{\rho_{l \jmath}}$ represents the unconditional correlation between the industry returns. The standardized residuals at time $t-1$, $u_{i, t-1}$ and $u_{j, t-1}$, are calculated from $\varepsilon_{i, t-1}, h_{i i, t-1}$ and $\varepsilon_{j, t-1}, h_{j j, t-1}$ respectively.

For each industry pair, we use the AIC to choose the best-fitting specification among the four DCC models: $\operatorname{GARCH}(1,1), \operatorname{GARCH}(2,1), \operatorname{GARCH}(1,2)$ and $\operatorname{GARCH}(2,2)$. We find consistent evidence of volatility transmission between industries: the GARCH spillover coefficients are statistically significant for $47.5 \%$ of the industry pairs in the sample while the ARCH spillover coefficients for $63.6 \%$ of the pairs. Volatility transmission (either GARCH or ARCH) is significant for $82.6 \%$ of the pairs. Detailed summary statistics of the first stage DCCbivariate GARCH estimates are reported in Appendix C Table C.1. We present in Table 9 the second-stage cross-sectional results. The sign and the significance of all the coefficients mirror those in Table 5, confirming the significant impact of business linkages on volatility spillovers between industries even when we permit the conditional correlation structure to vary over time.

\subsection{A trivariate GARCH approach}

We now extend our GARCH model to a trivariate setting. Our approach is as follows. For each industry pair $i$ and $j$, we create a value-weighted portfolio of the other 63 industries, which we refer to as $O$ (i.e., other industry partners). A trivariate GARCH specification, shown in detail in Appendix D, enables each industry $i$ 's excess return to be explained by its lagged excess 
return, the lagged excess return of the partner industry $j$, the lagged excess return of the portfolio $O$ of the other industries, the change in the short-term interest rate and the percentage change in the foreign exchange rate index. The volatility of the excess return of an industry $i$ is specified as a function of its own lagged volatility and lagged shocks, the lagged volatility and lagged shocks of its partner $j$, as well as those of the portfolio of the remaining industries.

As in our bivariate setting, we use the estimated volatility and the estimated shock spillover coefficients between industries $i$ and $j$ as the dependent variables in the second-stage cross-sectional analysis. The estimates presented in Table D.1 reinforce our earlier findings of a strong link between business linkages and volatility and shock spillovers between industries.

\subsection{Industry linkage variables calculated from different IO matrices}

The business linkage variables in the second stage analysis presented so far are calculated using the 2007 IO benchmark matrices (except Table 6). Although the structure of the inter-industry trading in a developed market like the US is expected to stay relatively stable over time, we test this conjecture by constructing the business linkage variables using information from: (i) the estimated IO tables of each year, (ii) an alternative benchmark IO table (year 2012), and (iii) the average trading relationship values within our sample period (2005-2013). These second-stage results are reported in Appendix E Table E.1. They are similar to those in Table 5 using the 2007 benchmark, confirming both the stable structure of the US economy and our earlier findings regarding the impact of business linkages on volatility spillovers.

\subsection{Exclusion of financial industries}

The financial sector is likely to have stronger volatility spillover effects on the rest of the economy. Here, we check whether our results are due to the six industries in the financial sector. We drop these industries (Federal Reserve Bank, credit intermediation and related activities; Securities, commodity contracts and investments; Insurance carriers and related activities; Funds, trusts, and other financial vehicles; Real estate; and Rental and leasing services and lessors of intangible assets) from the industry pool and conduct our two-stage analysis on the sample of non-financial industries. The results in Table E.2 confirm the importance of the business linkages on volatility spillovers between non-financial industries. 


\subsection{Industry pairs with substantial trade flows}

Close inspection of our dataset shows that a number of industries trade relatively little with each other. To account for very low trade flows between some industries, we sample only pairs of closely related industries. We classify an industry pair as having a substantial trade flow if the value of any of the four trading relationship variables $\left(C U S T_{i j}, S U P P_{i j}, C U S T_{j i}, S U P P_{j i}\right)$ is at least 1 percent. As shown in Table 3 and discussed in Section 3.4, 752 industry pairs pass this cut-off level. We conduct our two-stage volatility spillover analysis on the sample of closely related industries and report the second stage results in Table E.3. The similarity of these estimates to our main results reported earlier confirm the robustness of our findings.

\section{Conclusions}

This paper investigates whether the strength of the customer-supplier relationship can explain the characteristics of volatility spillovers among the US industries. Our approach consists of two stages. In the first stage, we employ a bivariate GARCH model to quantify the degree of spillovers between industry pairs in the US. The results from the first stage suggest that crossindustry volatility spillovers are indeed prevalent: $83 \%$ of the industry pairs under investigation are found to exhibit either GARCH or ARCH volatility spillovers.

In the second stage, we examine if the estimated degree of spillover can be explained by the strength of the customer-supplier relationship. We measure the strength of the business linkages using information from the IO accounts. Our expectation is that industries with high shares of revenues or inputs relative to their trading partners exhibit greater degrees of volatility spillover toward their partners. Our findings confirm this. The extent to which volatility tends to spread from an industry to its trading partner depends on its relative importance in the customer-supplier relationship between the trading industry pair. Interestingly, an industry which plays a more essential role in the partnership is better protected from volatility spillovers originating from its trading partner.

We investigate whether volatility spillovers are present at the portfolio level as well. Following Menzly and Ozbas (2010), we use the IO data to construct the portfolios of suppliers/ customers for each US industry and their degree of concentration. Our results suggest significant volatility spillovers for 61 out of 65 industries and confirm the link between the strength of the business relationship and volatility spillovers at the portfolio level.

We subject our results to a variety of sensitivity checks. Our results remain qualitatively intact under different GARCH frameworks, including the dynamic conditional correlation 
(DCC) GARCH and the trivariate GARCH, or when we calculate the measure of the strength of the customer-supplier relationship using information from different annual IO accounts. We also conduct our two-stage analysis on a number of restricted samples: (i) industry pairs with substantial trade flows; (ii) non-financial industries; (iii) samples separated by the financial crisis. Our results remain virtually unaltered: we observe substantial spillovers between industries and the strength of the customer-supplier relationship appears to be a good predictor of the degree of spillovers. Moreover, the strength of the business linkages seems to matter more during bad market conditions.

Our findings of volatility interdependence between industries in a trading relationship are useful for investors whose portfolios concentrate on some specific industries or sectors. By observing the volatility of the closely related industries, investors are able to better predict the volatility of their positions, which is essential to achieve an enhanced risk-return profile. Understanding the volatility transmission between industries is important for policy makers as well, since awareness about how a policy change in a specific sector could cause business uncertainty in related sectors would be essential.

A natural extension of our study would be the investigation of tail-dependent spillovers between related industries by exploiting the information on higher moments such as skewness or kurtosis spillovers. Another research direction would be the examination of volatility spillovers between related firms and the possible impact of their actual business relationship.

\section{Acknowledgments}

We would like to thank an anonymous reviewer and associate editor, the editor (Geert Bekaert), participants at the World Finance Conference 2017, Royal Economic Society 2016 conference, the Scottish Economic Society 2016 conference, seminar audience at Loughborough University, Shamim Ahmed, Kevin Amess, Stephen Hall, Linh Hoang Nguyen, Giorgio Valente, Dev Vencappa, and Piercarlo Zanchettin. We are grateful for access to the University of Nottingham High Performance Computing Facility. The usual disclaimer applies.

\section{REFERENCES}

Acemoglu, D., Carvalho, V.M., Ozdaglar, A., Tahbaz-Salehi, A. 2012. The network origins of aggregate fluctuations. Econometrica, 80(5), pp.1977-2016.

Acemoglu, D., Ozdaglar, A., Tahbaz-Salehi, A., 2017. Microeconomic origins of macroeconomic tail risks. American Economic Review, 107(1), pp.54-108. 
Ahern, K.R., 2013. Network centrality and the cross section of stock returns. Available at SSRN 2197370.

Ahern, K.R., Harford, J., 2014. The importance of industry links in merger waves. Journal of Finance, 69(2), pp.527-576.

Alli, K., Thapa, S., Yung, K., 1994. Stock price dynamics in overlapped market segments: Intra and Inter-industry contagion effects. Journal of Business Finance, Accounting, 21(7), pp.1059-1071.

Aobdia, D., Caskey, J., Ozel, N.B., 2014. Inter-industry network structure and the cross-predictability of earnings and stock returns. Review of Accounting Studies, 19, pp.1191-1224

Arouri, M.E.H., Jouini, J., Nguyen, D.K., 2011. Volatility spillovers between oil prices and stock sector returns: Implications for portfolio management. Journal of International Money and Finance, 30(7), pp.1387-1405.

Bali, T.G., Engle, R.F., 2010. The intertemporal capital asset pricing model with dynamic conditional correlations. Journal of Monetary Economics. 57(4), pp. 377-390.

Becker, M.J., Thomas, S.E., 2011. Changes in concentration across vertically related industries. Available at: http://papers.ssrn.com/abstract $=1816638$

Bollerslev, T., 1986. Generalized autoregressive conditional heteroskedasticity. Journal of Econometrics, 31, pp.307-327.

Bollerslev, T., 1990. Modelling the coherence in short-run nominal exchange rates: A multivariate generalized ARCH model, Review of Economics and Statistics, 72(3), pp.498-505.

Booth, G.G., Martikainen, T., Tse, Y., 1997. Price and volatility spillovers in Scandinavian stock markets. Journal of Banking and Finance, 21(6), pp.811-823.

Campbell, J.Y., Hamao, Y., 1992. Predictable stock returns in the United States and Japan : A study of long-term capital market integration. The Journal of Finance, XLVII(1), pp.43-69.

Carvalho, V.M., 2014. From micro to macro via production networks. Journal of Economic Perspectives, 28(4), pp.23-48

Cohen, L., Frazzini, A., 2008. Economic links and predictable returns. Journal of Finance, 63(4), pp.1977-2011.

Dale-Olsen, H., 2012. Executive pay determination and firm performance - Empirical evidence from a compressed wage environment. The Manchester School, 80(3), pp.355-376.

Elyasiani, E., Mansur, I., Pagano, M.S., 2007. Convergence and risk-return linkages across financial service firms. Journal of Banking and Finance, 31(4), pp.1167-1190.

Engle, R.F., 1982. Autoregressive conditional heteroscedasticity with estimates of the variance of United Kingdom inflation. Econometrica, 50(4), pp.987-1007.

Ewing, B.T., Malik, F., Ozfidan, O., 2002. Volatility transmission in the oil and natural gas markets. Energy Economics, 24(6), pp.525-538.

Gabaix, X. 2011. The granular origins of aggregate fluctuations. Econometrica, 79(3), 733-772

Griffin, J.M., Karolyi, G.A., 1998. Another look at the role of the industrial structure of markets for 
international diversification strategies. Journal of Financial Economics, 50(3), pp.351-373.

Hamao, Y., Masulis, R.W., Ng, V., 1990. Correlations in price changes and volatility across international stock markets. Review of Financial Studies, 3 (2), pp.281-307.

Hosking, J.R., 1980. The multivariate Portmanteau statistic. Journal of the American Statistical Association, 75(371), pp.602-608.

Kelly, B., Lustig, H., Van Nieuwerburgh, S., 2013. Firm volatility in granular networks (No. w19466). National Bureau of Economic Research.

King, M., Wadhwani, S., 1990. Transmission of volatility between stock markets. The Review of Financial Studies, 3(1), pp.5-33.

Kohonen, A., 2013. On detection of volatility spillovers in overlapping stock markets. Journal of Empirical Finance, 22, pp.140-158.

Koutmos, G., Booth, G.G., 1995. Asymmetric volatility transmission in international stock markets. Journal of International Money and Finance, 14(6), pp.747-762.

Lewis, J.B., Linzer, D.A., 2005. Estimating regression models in which the dependent variable is based on estimates. Political analysis, 13(4), pp.345-364.

Li, W.K., McLeod, A.I., 1981. Distribution of the residual autocorrelations in multivariate ARMA time series models. Journal of the Royal Statistical Society. Series B (Methodological), pp.231-239.

Ljung, G.M., Box, G.E., 1978. On a measure of lack of fit in time series models. Biometrika, 65(2), pp.297-303.

Menzly, L., Ozbas, O., 2010. Market segmentation and cross-predictability of returns. Journal of Finance, 65(4), pp.1555-1580.

Miyakoshi, T., 2003. Spillovers of stock return volatility to Asian equity markets from Japan and the US. Journal of International Financial Markets, Institutions and Money, 13(4), pp.383-399.

Shea, J., 2002. Complementarities and comovements. Journal of Money, Credit and Banking, 34(2), pp.412-433.

Wang, Z., 2010. Dynamics and causality in industry-specific volatility. Journal of Banking and Finance, 34(7), pp.1688-1699.

Weiß, G.N., Neumann, S., Bostandzic, D., 2014. Systemic risk and bank consolidation: International evidence. Journal of Banking and Finance, 40, pp.165-181. 
Fig. 1. Business linkages for the primary metals (PM) industry

Panel A. Input-Output linkages between primary metals (PM) and its trading partners

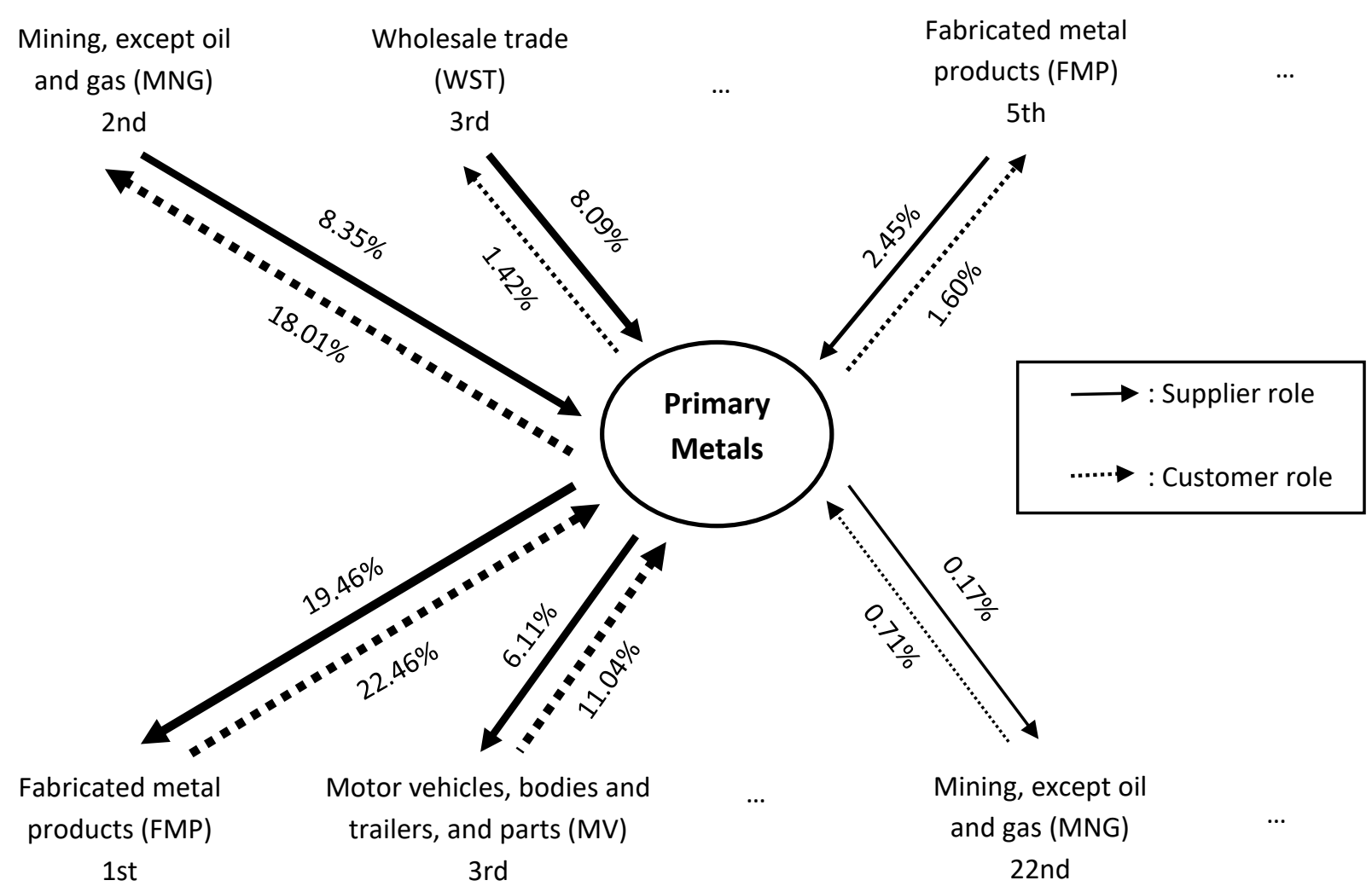

The figure shows the business linkages between primary metals (PM) and its trading industry partners. The upper (lower) row ranks PM's suppliers (customers) in descending order of the strength of the business linkages. Solid (dashed) arrows indicate supplier (customer) role. The width of the arrow is proportional to the percentage of the supplier (customer) role obtained from the CUST and SUPP matrices calculated based on the 2007 Input-Output Tables. While PM is its own largest supplier $\left(S U P P_{i i}=25.24 \%\right)$ and second largest customer $\left(C U S T_{i i}=22.06 \%\right)$, we do not list it with its trading partners above.

Panel B. The relationship variables for PM and MNG

The four business linkage measures for the pair of industries PM (industry $i$ ) and MNG (industry $j$ ) are:

\begin{tabular}{ccc}
\hline Business linkage & Percentage & \multicolumn{1}{c}{ Explanation } \\
\hline$S U P P_{j i}$ & $8.35 \%$ & $8.35 \%$ of PM's input is purchased from MNG \\
$C U S T_{j i}$ & $18.01 \%$ & $18.01 \%$ of MNG's revenue is generated from trades with PM \\
$S U P P_{i j}$ & $0.17 \%$ & $0.17 \%$ of MNG's input is purchased from PM \\
$C U S T_{i j}$ & $0.71 \%$ & $0.71 \%$ of PM's revenue is generated from trades with MNG \\
\hline
\end{tabular}


Table 1

Summary statistics of macroeconomic variables and industry characteristics

\begin{tabular}{|c|c|c|c|c|c|c|c|}
\hline & $\begin{array}{r}\text { Number of } \\
\text { Observations }\end{array}$ & Mean & Median & $\begin{array}{r}\text { Standard } \\
\text { deviation }\end{array}$ & Skewness & Min & Max \\
\hline \multicolumn{8}{|c|}{ Panel 1: Time series statistics of macroeconomic variables } \\
\hline Market return $(\%)$ & 2,264 & 0.038 & 0.098 & 1.342 & -0.173 & -8.976 & 11.490 \\
\hline Percentage change in FX index $(\%)$ & 2,264 & -0.004 & -0.012 & 0.332 & -0.004 & -2.275 & 1.748 \\
\hline Change in risk-free rate $(\%)$ & 2,264 & -0.002 & 0.000 & 0.058 & -1.166 & -0.810 & 0.740 \\
\hline \multicolumn{8}{|c|}{ Panel 2: Cross-sectional statistics of industry variables } \\
\hline Industry size & 63 & 97,190 & 22,954 & 171,865 & 2.443 & 241 & 799,811 \\
\hline Industry concentration ratio $(\%)$ & 56 & 27.868 & 23.250 & 19.083 & 0.946 & 4.000 & 85.000 \\
\hline
\end{tabular}

This table provides summary statistics. Panel 1 reports the descriptive statistics of the time series used in the first-stage regression: the market returns, the percentage change in the foreign exchange index, and the change in the risk-free rate over the period 1 January 2005 - 31 December 2013 . Panel 2 presents statistics for the cross-sectional industry data used in the second-stage analysis. Industry size (the number of firms in an industry) and (the eight-firm) concentration ratio statistics refer to 2007. 
Table 2

Summary statistics of CUST and SUPP variables

\begin{tabular}{|c|c|c|c|c|c|c|c|c|c|}
\hline \multicolumn{10}{|c|}{ Panel 1: CUST (\%) } \\
\hline & 2005 & 2006 & 2007 & 2008 & 2009 & 2010 & 2011 & 2012 & 2013 \\
\hline Mean & 0.671 & 0.664 & 0.668 & 0.664 & 0.635 & 0.642 & 0.646 & 0.647 & 0.653 \\
\hline Median & 0.109 & 0.107 & 0.110 & 0.109 & 0.103 & 0.103 & 0.102 & 0.108 & 0.107 \\
\hline 5th percentile & 0.001 & 0.001 & 0.001 & 0.001 & 0.001 & 0.001 & 0.001 & 0.001 & 0.001 \\
\hline 95th percentile & 2.452 & 2.438 & 2.583 & 2.557 & 2.363 & 2.352 & 2.425 & 2.451 & 2.472 \\
\hline \multicolumn{10}{|c|}{ Frequency percentage } \\
\hline 0 to $1 \%$ & 87.030 & 87.219 & 87.077 & 86.698 & 87.669 & 87.172 & 87.172 & 87.219 & 87.337 \\
\hline $1 \%$ to $2 \%$ & 6.414 & 6.509 & 6.651 & 6.746 & 6.249 & 6.391 & 6.320 & 6.438 & 6.201 \\
\hline $2 \%$ to $3 \%$ & 2.675 & 2.391 & 2.107 & 2.296 & 2.083 & 2.367 & 2.391 & 2.154 & 2.296 \\
\hline $3 \%$ to $4 \%$ & 0.828 & 0.970 & 1.183 & 1.325 & 1.112 & 1.136 & 1.160 & 1.231 & 1.089 \\
\hline $4 \%$ to $5 \%$ & 0.568 & 0.450 & 0.544 & 0.497 & 0.521 & 0.639 & 0.592 & 0.473 & 0.592 \\
\hline over $5 \%$ & 2.485 & 2.462 & 2.438 & 2.414 & 2.367 & 2.296 & 2.367 & 2.485 & 2.485 \\
\hline \multicolumn{10}{|c|}{ Panel 2: SUPP (\%) } \\
\hline & 2005 & 2006 & 2007 & 2008 & 2009 & 2010 & 2011 & 2012 & 2013 \\
\hline Mean & 0.836 & 0.836 & 0.841 & 0.834 & 0.800 & 0.821 & 0.832 & 0.835 & 0.841 \\
\hline Median & 0.152 & 0.148 & 0.147 & 0.146 & 0.140 & 0.150 & 0.148 & 0.150 & 0.155 \\
\hline 5 th percentile & 0.001 & 0.001 & 0.000 & 0.001 & 0.001 & 0.001 & 0.001 & 0.001 & 0.001 \\
\hline 95th percentile & 3.618 & 3.622 & 3.602 & 3.625 & 3.506 & 3.522 & 3.656 & 3.635 & 3.570 \\
\hline \multicolumn{10}{|c|}{ Frequency percentage } \\
\hline 0 to $1 \%$ & 81.870 & 82.012 & 81.751 & 81.941 & 82.414 & 82.201 & 82.249 & 82.272 & 82.343 \\
\hline $1 \%$ to $2 \%$ & 8.118 & 8.000 & 8.118 & 8.047 & 8.024 & 8.284 & 8.189 & 7.953 & 7.882 \\
\hline $2 \%$ to $3 \%$ & 3.834 & 3.763 & 3.763 & 3.716 & 3.432 & 3.550 & 3.456 & 3.598 & 3.527 \\
\hline $3 \%$ to $4 \%$ & 1.751 & 1.822 & 1.917 & 1.870 & 1.964 & 1.657 & 1.633 & 1.633 & 1.728 \\
\hline $4 \%$ to $5 \%$ & 1.018 & 0.970 & 1.041 & 0.994 & 1.065 & 0.923 & 1.065 & 1.136 & 1.112 \\
\hline over $5 \%$ & 3.408 & 3.432 & 3.408 & 3.408 & 3.101 & 3.385 & 3.408 & 3.408 & 3.408 \\
\hline
\end{tabular}

This table presents the statistics of the CUST and SUPP variables calculated from the IO tables from 2005 to 2013. The mean, median, 5\% and 95\% quantiles of the distribution of values in the constructed CUST and SUPP matrices, as well as the proportion (frequency percentage) of different value ranges are reported in separate panels for $C U S T$ and $S U P P$, respectively. 
Table 3

Descriptive statistics of business linkages between industries

Panel 1:

\begin{tabular}{|c|c|c|c|c|c|c|c|c|c|c|c|}
\hline & & \multicolumn{10}{|c|}{ Threshold (\%) } \\
\hline & & 1 & 2 & 3 & 4 & 5 & 6 & 7 & 8 & 9 & 10 \\
\hline$(1)$ & $\begin{array}{l}\text { Pairs with weak linkage } \\
\text { sc - sc }\end{array}$ & 1328 & 1637 & 1790 & 1877 & 1930 & 1966 & 1984 & 2003 & 2017 & 2024 \\
\hline & Pairs with close linkage & 752 & 443 & 290 & 203 & 150 & 114 & 96 & 77 & 63 & 56 \\
\hline$(2)$ & $\mathrm{sC}-\mathrm{sc}$ & 108 & 69 & 60 & 49 & 38 & 32 & 31 & 29 & 27 & 28 \\
\hline (3) & $\mathrm{Sc}-\mathrm{sc}$ & 294 & 222 & 149 & 109 & 74 & 53 & 47 & 33 & 26 & 20 \\
\hline (4) & $\mathrm{SC}-\mathrm{sc}$ & 67 & 28 & 13 & 4 & 2 & 1 & 1 & 1 & 1 & 1 \\
\hline$(5)$ & $\mathrm{sC}-\mathrm{sC}$ & 0 & 0 & 0 & 0 & 0 & 0 & 0 & 0 & 0 & 0 \\
\hline (6) & $\mathrm{Sc}-\mathrm{sC}$ & 187 & 104 & 62 & 38 & 34 & 26 & 16 & 13 & 8 & 7 \\
\hline$(7)$ & $\mathrm{SC}-\mathrm{sC}$ & 15 & 4 & 2 & 1 & 0 & 0 & 0 & 0 & 0 & 0 \\
\hline$(8)$ & $\mathrm{Sc}-\mathrm{Sc}$ & 1 & 0 & 0 & 0 & 0 & 0 & 0 & 0 & 0 & 0 \\
\hline$(9)$ & $\mathrm{SC}-\mathrm{Sc}$ & 50 & 12 & 3 & 1 & 2 & 2 & 1 & 1 & 1 & 0 \\
\hline (10) & $\mathrm{SC}-\mathrm{SC}$ & 30 & 4 & 1 & 1 & 0 & 0 & 0 & 0 & 0 & 0 \\
\hline
\end{tabular}


Panel 2: Pairs with close linkages

\begin{tabular}{|c|c|c|c|c|c|c|c|c|c|c|}
\hline & \multicolumn{10}{|c|}{ Threshold (\%) } \\
\hline & 1 & 2 & 3 & 4 & 5 & 6 & 7 & 8 & 9 & 10 \\
\hline $\begin{array}{l}\text { Pairs with one direction close linkage } \\
\text { [groups }(2),(3),(6) \text { ] }\end{array}$ & 589 & 395 & 271 & 196 & 146 & 111 & 94 & 75 & 61 & 55 \\
\hline $\begin{array}{l}\text { Pairs with at least one main supplier } \\
\text { [groups }(3),(4),(6),(7),(8),(9),(10) \text { ] }\end{array}$ & 644 & 374 & 230 & 154 & 112 & 82 & 65 & 48 & 36 & 28 \\
\hline $\begin{array}{l}\text { Pairs with at least one main customer } \\
\text { [groups }(2),(4),(5),(6),(7),(9),(10)]\end{array}$ & 457 & 221 & 141 & 94 & 76 & 61 & 49 & 44 & 37 & 36 \\
\hline $\begin{array}{l}\text { One industry as both main supplier and main customer } \\
\text { [groups }(4),(7),(9),(10) \text { ] }\end{array}$ & 162 & 48 & 19 & 7 & 4 & 3 & 2 & 2 & 2 & 1 \\
\hline $\begin{array}{l}\text { Both industries are main suppliers } \\
\text { [groups }(8),(9),(10) \text { ] }\end{array}$ & 81 & 16 & 4 & 2 & 2 & 2 & 1 & 1 & 1 & 0 \\
\hline $\begin{array}{l}\text { Both industries are main customers } \\
\text { [groups }(5),(7),(10) \text { ] }\end{array}$ & 45 & 8 & 3 & 2 & 0 & 0 & 0 & 0 & 0 & 0 \\
\hline
\end{tabular}

This table presents summary statistics for the 2,080 industry pairs according to the strength of their trading relationship (based on the 2007 IO data). Panel 1 displays the 10 possible combinations of the supplier and customer roles in an industry pair. An industry is classified as a main customer / supplier relative to its partner if its corresponding CUST / SUPP value is at least equal to the classifying threshold, which ranges from $1 \%$ to $10 \%$ (by columns). Capital letters (S and C) denote main supplier / customer, while small letters (s and c) denote small supplier / customer, respectively. For example, Sc - sC stands for pairs in which industry $i$ is a main supplier and small customer of industry $j$, and industry $j$ is a small supplier and main customer of industry $i$. Panel 2 provides details for the pairs with close linkages identified in Panel 1. 
Table 4

Summary statistics of the bivariate volatility spillover model estimates

\begin{tabular}{|c|c|c|c|c|c|c|}
\hline & Coefficients & Mean & Min & $\operatorname{Max}$ & $\begin{array}{c}\text { Number } \\
(t>1.645)\end{array}$ & $\%(t>1.645)$ \\
\hline$\alpha_{M 1}$ & Market return - Industry & 1.070 & 0.591 & 1.645 & 2080 & 100.00 \\
\hline$\alpha_{F X 1}$ & $\%$ change in FX index - Industry & 0.010 & -0.356 & 0.500 & 281 & 13.51 \\
\hline$\alpha_{\triangle R F 1}$ & Change in risk-free rate - Industry & -0.024 & -3.585 & 2.385 & 704 & 33.85 \\
\hline$\alpha_{M 2}$ & Market return - Partner & 1.058 & 0.558 & 1.646 & 2080 & 100.00 \\
\hline$\alpha_{F X 2}$ & $\%$ change in FX index - Partner & 0.011 & -0.326 & 0.428 & 257 & 12.36 \\
\hline$\alpha_{\triangle R F 2}$ & Change in risk-free rate - Partner & 0.010 & -3.276 & 2.620 & 673 & 32.36 \\
\hline$\alpha_{11}$ & Industry's return autocorrelation & 0.008 & -0.128 & 0.138 & 756 & 36.35 \\
\hline$\alpha_{22}$ & Partner's return autocorrelation & 0.012 & -0.137 & 0.136 & 763 & 36.68 \\
\hline$\alpha_{12}$ & Return spillover Partner-Industry & 0.006 & -0.114 & 0.237 & 488 & 23.46 \\
\hline$\alpha_{21}$ & Return spillover Industry-Partner & 0.008 & -0.207 & 0.212 & 565 & 27.16 \\
\hline$\beta_{11,1}$ & Industry's GARCH lag 1 & 0.433 & 0.000 & 0.991 & 1321 & 63.51 \\
\hline$\beta_{22,1}$ & Partner's GARCH lag 1 & 0.405 & 0.000 & 0.989 & 1330 & 63.94 \\
\hline$\gamma_{11,1}$ & Industry's ARCH lag 1 & 0.080 & 0.000 & 0.582 & 2005 & 96.39 \\
\hline$\gamma_{22,1}$ & Partner's ARCH lag 1 & 0.083 & 0.000 & 0.455 & 2018 & 97.02 \\
\hline$\beta_{11,2}$ & Industry's GARCH lag 2 & 0.519 & 0.000 & 0.968 & 1148 & $73.40^{*}$ \\
\hline$\beta_{22,2}$ & Partner's GARCH lag 2 & 0.499 & 0.000 & 0.974 & 1157 & $73.98 *$ \\
\hline$\gamma_{11,2}$ & Industry's ARCH lag 2 & 0.041 & 0.000 & 0.265 & 293 & $52.32 *$ \\
\hline$\gamma_{22,2}$ & Partner's ARCH lag 2 & 0.076 & 0.000 & 0.722 & 353 & $63.04 *$ \\
\hline$\rho_{i j}$ & Correlation & 0.030 & -0.381 & 0.735 & 1516 & 72.88 \\
\hline
\end{tabular}




\begin{tabular}{|c|c|c|c|c|c|c|}
\hline & Coefficients & Mean & Min & Max & $\begin{array}{l}\text { Number } \\
(t>1.645)\end{array}$ & $\%(t>1.645)$ \\
\hline$\beta_{12}$ & GARCH spillover Partner-Industry & 0.078 & 0.000 & 8.623 & 449 & 21.59 \\
\hline$\beta_{21}$ & GARCH spillover Industry-Partner & 0.220 & 0.000 & 13.966 & 607 & 29.18 \\
\hline$\gamma_{12}$ & ARCH spillover Partner-Industry & 0.033 & 0.000 & 2.643 & 796 & 38.27 \\
\hline$\gamma_{21}$ & ARCH spillover Industry-Partner & 0.068 & 0.000 & 10.738 & 891 & 42.84 \\
\hline
\end{tabular}

This table shows summary statistics for the coefficient estimates obtained from Eqs. (1)-(6).

$$
\begin{aligned}
& R_{i, t}=\alpha_{10}+\alpha_{M 1} R_{M t}+\alpha_{F X 1} F X_{t-1}+\alpha_{\Delta R F 1} \Delta R F_{t-1}+\alpha_{11} R_{i, t-1}+\alpha_{12} R_{j, t-1}+\varepsilon_{i, t} \\
& h_{i i, t}=\beta_{10}+\sum_{k=1}^{p} \beta_{11 k} h_{i i, t-k}+\sum_{l=1}^{q} \gamma_{11 l} \varepsilon_{i, t-l}^{2}+\beta_{12} h_{j j, t-1}+\gamma_{12} \varepsilon_{j, t-1}^{2} \\
& R_{j, t}=\alpha_{20}+\alpha_{M 2} R_{M t}+\alpha_{F X 2} F X_{t-1}+\alpha_{\Delta R F 2} \Delta R F_{t-1}+\alpha_{22} R_{j, t-1}+\alpha_{21} R_{i, t-1}+\varepsilon_{j, t} \\
& h_{j j, t}=\beta_{20}+\sum_{k=1}^{p} \beta_{22 k} h_{j j, t-k}+\sum_{l=1}^{q} \gamma_{22 l} \varepsilon_{j, t-l}^{2}+\beta_{21} h_{i i, t-1}+\gamma_{21} \varepsilon_{i, t-1}^{2} \\
& \varepsilon_{i, t}\left|\Omega_{t-1} \sim N\left(0, h_{i i, t}\right) ; \varepsilon_{j, t}\right| \Omega_{t-1} \sim N\left(0, h_{j j, t}\right) \\
& h_{i j, t}=\rho_{i j} \sqrt{h_{i i, t} h_{j j, t}}, i \neq j
\end{aligned}
$$

The bivariate volatility spillover model is estimated for each industry pair using 2,264 daily observations. The table reports the mean, the minimum, and the maximum value of the estimated coefficients for the 2,080 industry pairs; the number and percentage of estimated coefficients significant at $10 \%$ level (t-statistics above 1.645 ).

* These statistics are based on the number of best-fitting models which include these lags as shown below. For example, the coefficient of industry's GARCH lag 2 is statistically significant for 1,148 industry pairs among the 1,564 best-fitting $\operatorname{GARCH}(2,1)$ and $\operatorname{GARCH}(2,2)$ models $(73.40 \%)$.

$\begin{array}{lr}\text { Model } & \text { Number of best-fitting models } \\ \text { GARCH }(1,1) & 415 \\ \text { GARCH }(2,1) & 1,105 \\ \text { GARCH }(1,2) & 101 \\ \text { GARCH }(2,2) & 459\end{array}$


Table 5

Business linkages and volatility spillover in 2005-2013

\begin{tabular}{|c|c|c|c|c|c|c|c|c|}
\hline & \multicolumn{4}{|c|}{ GARCH spillover } & \multicolumn{4}{|c|}{ ARCH spillover } \\
\hline & $(1)$ & $(2)$ & (3) & $(4)$ & $(5)$ & $(6)$ & $(7)$ & $(8)$ \\
\hline Customer role of Industry & 1.300 & 1.177 & 3.493 & 2.913 & $0.269 *$ & 0.153 & $0.519 *$ & 0.342 \\
\hline$\left(C U S T_{j i}\right)$ & (1.096) & $(1.253)$ & $(2.694)$ & $(2.720)$ & $(0.152)$ & $(0.182)$ & $(0.304)$ & $(0.315)$ \\
\hline Supplier role of Industry & 0.579 & 0.514 & 0.799 & 0.394 & $0.635^{*}$ & $0.589 *$ & $1.184 * * *$ & $1.045 * * *$ \\
\hline$\left(S U P P_{i j}\right)$ & $(0.515)$ & $(0.513)$ & $(0.843)$ & $(0.821)$ & $(0.337)$ & $(0.330)$ & $(0.378)$ & $(0.328)$ \\
\hline Customer role of Partner & $-0.924 * * *$ & $-0.967 * * *$ & $-1.710 * *$ & $-1.101 *$ & $-0.497 * * *$ & $-0.503 * * *$ & $-1.026^{* * *}$ & $-0.843 * * *$ \\
\hline$\left(C U S T_{i j}\right)$ & $(0.310)$ & $(0.307)$ & $(0.688)$ & $(0.588)$ & $(0.179)$ & $(0.181)$ & $(0.355)$ & $(0.295)$ \\
\hline Supplier role of Partner & $-2.050 * *$ & $-2.083^{*}$ & $-4.893 * * *$ & $-4.186^{* * *}$ & $-0.521 * *$ & $-0.491 * *$ & $-1.134 * * *$ & $-0.935 * * *$ \\
\hline$\left(S U P P_{j i}\right)$ & $(0.983)$ & $(1.107)$ & $(1.333)$ & $(1.315)$ & $(0.212)$ & $(0.227)$ & $(0.223)$ & $(0.191)$ \\
\hline \multirow[t]{2}{*}{ Industry Size } & & 0.024 & & 0.113 & & 0.034 & & 0.047 \\
\hline & & $(0.078)$ & & $(0.142)$ & & $(0.033)$ & & $(0.046)$ \\
\hline \multirow[t]{2}{*}{ Partner Size } & & -0.047 & & $-0.354 * * *$ & & -0.013 & & $-0.095 * * *$ \\
\hline & & $(0.030)$ & & $(0.052)$ & & $(0.011)$ & & $(0.016)$ \\
\hline \multirow[t]{2}{*}{ Industry Concentration } & & & -0.001 & 0.032 & & & -0.032 & -0.018 \\
\hline & & & $(0.069)$ & $(0.087)$ & & & $(0.034)$ & $(0.028)$ \\
\hline \multirow[t]{2}{*}{ Partner Concentration } & & & $-0.628 * * *$ & $-0.735 * * *$ & & & $-0.149 * * *$ & $-0.178 * * *$ \\
\hline & & & $(0.083)$ & $(0.091)$ & & & $(0.032)$ & $(0.034)$ \\
\hline Observations & 4,160 & 3,906 & 3,080 & 3,080 & 4,160 & 3,906 & 3,080 & 3,080 \\
\hline Adjusted $\mathrm{R}^{2}$ & 0.003 & 0.002 & 0.025 & 0.027 & 0.002 & 0.002 & 0.011 & 0.012 \\
\hline
\end{tabular}

This table reports cross-sectional estimated coefficients and bootstrapped standard errors (in parentheses). The dependent variables are the GARCH spillover and the ARCH spillover coefficients obtained from the multivariate GARCH model (Eqs. (1)-(6)) using daily returns over the period 1 January 2005 - 31 December 2013. The relation between the two volatility spillover coefficients and the business linkage variables are specified in Eqs. (8) and (9). The business linkage variables, industry size (millions of firms) and the concentration ratios refer to year $2007 . * * *$ and $* * *$ denote the $10 \%, 5 \%$ and $1 \%$ significance levels, respectively. 
Table 6

Business linkages and volatility spillovers over different market conditions

Panel 1: 2005 - 2006

\begin{tabular}{|c|c|c|c|c|}
\hline & \multicolumn{2}{|c|}{ GARCH spillover } & \multicolumn{2}{|c|}{ ARCH spillover } \\
\hline & (1) & (2) & (3) & (4) \\
\hline $\begin{array}{l}\text { Customer role of Industry } \\
\left(C U S T_{j i}\right)\end{array}$ & $\begin{array}{c}3.332 * * \\
(1.663)\end{array}$ & $\begin{array}{l}3.261 * \\
(1.836)\end{array}$ & $\begin{array}{c}1.488 \\
(0.948)\end{array}$ & $\begin{array}{c}1.511 \\
(1.036)\end{array}$ \\
\hline $\begin{array}{l}\text { Supplier role of Industry } \\
\left(S U P P_{i j}\right)\end{array}$ & $\begin{array}{l}3.761 * \\
(2.274)\end{array}$ & $\begin{array}{c}3.397 \\
(2.325)\end{array}$ & $\begin{array}{l}0.906^{*} \\
(0.518)\end{array}$ & $\begin{array}{c}0.732 \\
(0.512)\end{array}$ \\
\hline $\begin{array}{l}\text { Customer role of Partner } \\
\left(C U S T_{i j}\right)\end{array}$ & $\begin{array}{l}-2.881 * * \\
(1.176)\end{array}$ & $\begin{array}{c}-2.777 * * \\
(1.240)\end{array}$ & $\begin{array}{c}-0.701 * * * \\
(0.264)\end{array}$ & $\begin{array}{c}-0.545^{* *} \\
(0.271)\end{array}$ \\
\hline $\begin{array}{l}\text { Supplier role of Partner } \\
\left(S U P P_{j i}\right)\end{array}$ & $\begin{array}{l}-3.688 * * \\
(1.536)\end{array}$ & $\begin{array}{c}-3.577 * * \\
(1.559)\end{array}$ & $\begin{array}{c}-1.389 * * \\
(0.667)\end{array}$ & $\begin{array}{l}-1.277^{*} \\
(0.687)\end{array}$ \\
\hline Industry Size & & $\begin{array}{c}0.180 \\
(0.149)\end{array}$ & & $\begin{array}{c}0.051 \\
(0.033)\end{array}$ \\
\hline Partner Size & & $\begin{array}{l}-0.130 \\
(0.090)\end{array}$ & & $\begin{array}{c}-0.077 * * * \\
(0.019)\end{array}$ \\
\hline Observations & 4,160 & 3,906 & 4,160 & 3,906 \\
\hline Adjusted $\mathrm{R}^{2}$ & 0.005 & 0.005 & 0.009 & 0.010 \\
\hline
\end{tabular}


Panel 2: 2007-2008

\begin{tabular}{|c|c|c|c|c|c|c|c|c|}
\hline & \multicolumn{4}{|c|}{ GARCH spillover } & \multicolumn{4}{|c|}{ ARCH spillover } \\
\hline & (1) & (2) & (3) & (4) & $(5)$ & $(6)$ & (7) & $(8)$ \\
\hline $\begin{array}{l}\text { Customer role of Industry } \\
\left(C U S T_{j i}\right)\end{array}$ & $\begin{array}{l}1.188^{*} \\
(0.646)\end{array}$ & $\begin{array}{c}1.078 \\
(0.780)\end{array}$ & $\begin{array}{l}2.870^{*} \\
(1.539)\end{array}$ & $\begin{array}{c}2.324 \\
(1.534)\end{array}$ & $\begin{array}{c}1.488 \\
(1.114)\end{array}$ & $\begin{array}{c}1.489 \\
(1.283)\end{array}$ & $\begin{array}{c}3.584 \\
(2.845)\end{array}$ & $\begin{array}{c}3.396 \\
(2.872)\end{array}$ \\
\hline $\begin{array}{l}\text { Supplier role of Industry } \\
\left(S U P P_{i j}\right)\end{array}$ & $\begin{array}{l}2.546^{*} \\
(1.382)\end{array}$ & $\begin{array}{c}2.311 \\
(1.406)\end{array}$ & $\begin{array}{c}4.266^{* * *} \\
(1.455)\end{array}$ & $\begin{array}{c}3.775 * * * \\
(1.366)\end{array}$ & $\begin{array}{l}1.012 * \\
(0.599)\end{array}$ & $\begin{array}{c}0.928 \\
(0.583)\end{array}$ & $\begin{array}{l}1.468 * * \\
(0.718)\end{array}$ & $\begin{array}{l}1.307 * \\
(0.693)\end{array}$ \\
\hline $\begin{array}{l}\text { Customer role of Partner } \\
\left(C U S T_{i j}\right)\end{array}$ & $\begin{array}{c}-1.609 * * \\
(0.641)\end{array}$ & $\begin{array}{c}-1.531 * * \\
(0.705)\end{array}$ & $\begin{array}{c}-3.221 * * * \\
(1.063)\end{array}$ & $\begin{array}{c}-2.671 * * * \\
(0.974)\end{array}$ & $\begin{array}{c}-0.882 * * * \\
(0.317)\end{array}$ & $\begin{array}{c}-0.954 * * * \\
(0.334)\end{array}$ & $\begin{array}{c}-1.256^{* *} \\
(0.622)\end{array}$ & $\begin{array}{l}-1.064 * \\
(0.570)\end{array}$ \\
\hline $\begin{array}{l}\text { Supplier role of Partner } \\
\left(S U P P_{j i}\right)\end{array}$ & $\begin{array}{c}-2.143 * * * \\
(0.832)\end{array}$ & $\begin{array}{l}-2.052 * * \\
(0.894)\end{array}$ & $\begin{array}{c}-4.031 * * * \\
(0.857)\end{array}$ & $\begin{array}{c}-3.497 * * * \\
(0.833)\end{array}$ & $\begin{array}{c}-1.587 * * \\
(0.809)\end{array}$ & $\begin{array}{l}-1.642 * \\
(0.893)\end{array}$ & $\begin{array}{c}-3.096 * * \\
(1.267)\end{array}$ & $\begin{array}{c}-2.901 * * \\
(1.294)\end{array}$ \\
\hline Industry Size & & $\begin{array}{c}0.145 \\
(0.097)\end{array}$ & & $\begin{array}{c}0.198 \\
(0.165)\end{array}$ & & $\begin{array}{c}0.027 \\
(0.051)\end{array}$ & & $\begin{array}{c}0.061 \\
(0.068)\end{array}$ \\
\hline Partner Size & & $\begin{array}{l}-0.050 \\
(0.052)\end{array}$ & & $\begin{array}{c}-0.233 * * * \\
(0.059)\end{array}$ & & $\begin{array}{c}0.013 \\
(0.026)\end{array}$ & & $\begin{array}{c}-0.088 * * * \\
(0.033)\end{array}$ \\
\hline Industry Concentration & & & $\begin{array}{c}0.009 \\
(0.060)\end{array}$ & $\begin{array}{c}0.068 \\
(0.078)\end{array}$ & & & $\begin{array}{l}-0.048 \\
(0.042)\end{array}$ & $\begin{array}{l}-0.030 \\
(0.040)\end{array}$ \\
\hline Partner Concentration & & & $\begin{array}{c}-0.208^{* *} \\
(0.103)\end{array}$ & $\begin{array}{c}-0.278^{* *} \\
(0.111)\end{array}$ & & & $\begin{array}{c}-0.224 * * * \\
(0.047)\end{array}$ & $\begin{array}{c}-0.251 * * * \\
(0.049)\end{array}$ \\
\hline Observations & 4,160 & 3,906 & 3,080 & 3,080 & 4,160 & 3,906 & 3,080 & 3,080 \\
\hline Adjusted $\mathrm{R}^{2}$ & 0.004 & 0.005 & 0.009 & 0.010 & 0.003 & 0.002 & 0.021 & 0.021 \\
\hline
\end{tabular}


Panel 3: 2009-2013

\begin{tabular}{|c|c|c|c|c|c|c|c|c|}
\hline & \multicolumn{4}{|c|}{ GARCH spillover } & \multicolumn{4}{|c|}{ ARCH spillover } \\
\hline & $(1)$ & $(2)$ & $(3)$ & $(4)$ & $(5)$ & $(6)$ & $(7)$ & $(8)$ \\
\hline $\begin{array}{l}\text { Customer role of Industry } \\
\left(C U S T_{j i}\right)\end{array}$ & $\begin{array}{c}1.669 \\
(1.389)\end{array}$ & $\begin{array}{c}1.796 \\
(1.862)\end{array}$ & $\begin{array}{c}3.969 \\
(3.230)\end{array}$ & $\begin{array}{c}3.508 \\
(3.298)\end{array}$ & $\begin{array}{c}0.022 \\
(0.229)\end{array}$ & $\begin{array}{l}-0.055 \\
(0.249)\end{array}$ & $\begin{array}{l}-0.033 \\
(0.261)\end{array}$ & $\begin{array}{l}-0.125 \\
(0.320)\end{array}$ \\
\hline $\begin{array}{l}\text { Supplier role of Industry } \\
\left(S U P P_{i j}\right)\end{array}$ & $\begin{array}{c}0.861 \\
(0.672)\end{array}$ & $\begin{array}{c}0.916 \\
(0.753)\end{array}$ & $\begin{array}{c}1.814 \\
(1.110)\end{array}$ & $\begin{array}{c}1.552 \\
(1.129)\end{array}$ & $\begin{array}{c}0.276 \\
(0.275)\end{array}$ & $\begin{array}{c}0.338 \\
(0.271)\end{array}$ & $\begin{array}{c}0.833 * * \\
(0.408)\end{array}$ & $\begin{array}{l}0.780 * * \\
(0.357)\end{array}$ \\
\hline $\begin{array}{l}\text { Customer role of Partner } \\
\left(C U S T_{i j}\right)\end{array}$ & $\begin{array}{c}-1.328 * * * \\
(0.501)\end{array}$ & $\begin{array}{c}-1.542 * * \\
(0.625)\end{array}$ & $\begin{array}{c}-2.568 * * * \\
(0.900)\end{array}$ & $\begin{array}{c}-1.965^{* *} \\
(0.833)\end{array}$ & $\begin{array}{c}-0.505^{* *} \\
(0.197)\end{array}$ & $\begin{array}{c}-0.659 * * \\
(0.267)\end{array}$ & $\begin{array}{c}-0.797 * * \\
(0.355)\end{array}$ & $\begin{array}{c}-0.678 * * \\
(0.303)\end{array}$ \\
\hline $\begin{array}{l}\text { Supplier role of Partner } \\
\left(S U P P_{j i}\right)\end{array}$ & $\begin{array}{l}-3.051 * * \\
(1.278)\end{array}$ & $\begin{array}{c}-3.125^{* *} \\
(1.445)\end{array}$ & $\begin{array}{c}-5.673 * * * \\
(1.520)\end{array}$ & $\begin{array}{c}-5.052 * * * \\
(1.524)\end{array}$ & $\begin{array}{l}-0.612 \\
(0.383)\end{array}$ & $\begin{array}{l}-0.657 \\
(0.442)\end{array}$ & $\begin{array}{c}-1.156^{* * *} \\
(0.242)\end{array}$ & $\begin{array}{c}-1.034 * * * \\
(0.219)\end{array}$ \\
\hline Industry Size & & $\begin{array}{l}-0.062 \\
(0.098)\end{array}$ & & $\begin{array}{c}0.014 \\
(0.147)\end{array}$ & & $\begin{array}{l}-0.060 \\
(0.048)\end{array}$ & & $\begin{array}{c}0.004 \\
(0.051)\end{array}$ \\
\hline Partner Size & & $\begin{array}{c}-0.090^{*} \\
(0.046)\end{array}$ & & $\begin{array}{c}-0.377 * * * \\
(0.063)\end{array}$ & & $\begin{array}{c}0.012 \\
(0.024)\end{array}$ & & $\begin{array}{c}-0.073 * * * \\
(0.024)\end{array}$ \\
\hline Industry Concentration & & & $\begin{array}{c}0.096 \\
(0.100)\end{array}$ & $\begin{array}{c}0.099 \\
(0.113)\end{array}$ & & & $\begin{array}{c}0.052 \\
(0.066)\end{array}$ & $\begin{array}{c}0.053 \\
(0.065)\end{array}$ \\
\hline Partner Concentration & & & $\begin{array}{c}-0.614 * * * \\
(0.103)\end{array}$ & $\begin{array}{c}-0.723 * * * \\
(0.112)\end{array}$ & & & $\begin{array}{c}-0.201 * * * \\
(0.052)\end{array}$ & $\begin{array}{c}-0.222 * * * \\
(0.056)\end{array}$ \\
\hline Observations & 4,032 & 3,782 & 2,970 & 2,970 & 4,032 & 3,782 & 2,970 & 2,970 \\
\hline Adjusted $\mathrm{R}^{2}$ & 0.003 & 0.003 & 0.020 & 0.021 & -0.000 & -0.000 & 0.007 & 0.007 \\
\hline
\end{tabular}

This table reports cross-sectional estimated coefficients and bootstrapped standard errors (in parentheses). The dependent variables are the GARCH spillover and the ARCH spillover coefficients obtained from the multivariate GARCH model (Eqs. (1)-(6)) using daily returns over three different periods: 1 January 2005 - 31 December 2006 (Panel 1), 1 January 2007 - 31 December 2008 (Panel 2) and 1 January 2009 - 31 December 2013 (Panel 3). The relation between the two volatility spillover coefficients and the business linkage variables are specified in Eqs. (8) and (9). The business linkage variables and the industry size (millions of firms) refer to year 2005 (Panel 1), 2007 (Panel 2) and 2012 (Panel 3). *** and $* * *$ denote the $10 \%, 5 \%$ and $1 \%$ significance levels, respectively. 
Table 7

Volatility spillover between industries and their representative trading partners

Panel 1: Industry and Representative Supplier

\begin{tabular}{lcccccc}
\hline & Obs & Min & Max & Mean & $\begin{array}{c}\text { No } \\
(\mathrm{t}>1.645)\end{array}$ & $\begin{array}{c}\% \\
(\mathrm{t}>1.645)\end{array}$ \\
\hline $\begin{array}{l}\text { GARCH spillover } \\
\text { (Industry to Representative Supplier) }\end{array}$ & 2264 & 0.000 & 0.187 & 0.006 & 8 & 12.31 \\
$\begin{array}{l}\text { GARCH spillover } \\
\text { (Representative Supplier to Industry) }\end{array}$ & 2264 & 0.000 & 5.896 & 0.526 & 16 & 24.62 \\
$\begin{array}{l}\text { ARCH spillover } \\
\text { (Industry to Representative Supplier) }\end{array}$ & 2264 & 0.000 & 0.053 & 0.003 & 15 & 23.08 \\
$\begin{array}{l}\text { ARCH spillover } \\
\text { (Representative Supplier to Industry) }\end{array}$ & 2264 & 0.000 & 2.127 & 0.308 & 34 & 52.31 \\
\hline
\end{tabular}

Panel 2: Industry and Representative Customer

\begin{tabular}{|c|c|c|c|c|c|c|}
\hline $\begin{array}{l}\text { GARCH spillover } \\
\text { (Representative Customer to Industry) }\end{array}$ & 2264 & 0.000 & 4.283 & 0.414 & 17 & 26.15 \\
\hline $\begin{array}{l}\text { GARCH spillover } \\
\text { (Industry to Representative Customer) }\end{array}$ & 2264 & 0.000 & 0.073 & 0.004 & 4 & 6.15 \\
\hline $\begin{array}{l}\text { ARCH spillover } \\
\text { (Representative Customer to Industry) }\end{array}$ & 2264 & 0.000 & 9.632 & 0.391 & 38 & 58.46 \\
\hline $\begin{array}{l}\text { ARCH spillover } \\
\text { (Industry to Representative Customer) }\end{array}$ & 2264 & 0.000 & 0.054 & 0.005 & 27 & 41.54 \\
\hline
\end{tabular}

Panel 3: Direction of volatility spillovers

\begin{tabular}{cccc}
\hline & GARCH & ARCH & $\begin{array}{c}\text { Either GARCH } \\
\text { or ARCH } \\
\text { spillover }\end{array}$ \\
\hline Spillovers to Industry & 33 & 72 & 89 \\
sumber industries affected by their partners & 23 & 47 & 54 \\
Spillovers from Industry & 12 & 42 & 50 \\
Number industries affecting their partners & 11 & 34 & 40 \\
\hline Downstream spillover cases & 20 & 61 & 69 \\
$\quad$ Representative Supplier to Industry & 16 & 34 & 40 \\
Industry to Representative Customer & 4 & 27 & 29 \\
Number industries involved in downstream spillover & 20 & 45 & 50 \\
\hline Upstream spillover cases & 25 & 53 & 70 \\
Industry to Representative Supplier & 8 & 15 & 21 \\
Representative Customer to Industry & 17 & 38 & 49 \\
Number industries involved in downstream spillover & 24 & 40 & 54 \\
\hline
\end{tabular}




\begin{tabular}{lllllll}
\hline \multicolumn{9}{c}{ Cases of volatility spillover } & \multicolumn{2}{c}{$\begin{array}{c}\text { Either GARCH or } \\
\text { ARCH spillover }\end{array}$} \\
\hline$(1)$ & $\mathrm{S}$ & $\cdots$ & $\mathrm{I}$ & $\rightarrow$ & $\mathrm{C}$ & 3 \\
$(2)$ & $\mathrm{S}$ & $\cdots$ & $\mathrm{I}$ & $\leftarrow$ & $\mathrm{C}$ & 5 \\
$(3)$ & $\mathrm{S}$ & $\cdots$ & $\mathrm{I}$ & $\leftrightarrow$ & $\mathrm{C}$ & 3 \\
$(4)$ & $\mathrm{S}$ & $\rightarrow$ & $\mathrm{I}$ & $\cdots$ & $\mathrm{C}$ & 2 \\
$(5)$ & $\mathrm{S}$ & $\rightarrow$ & $\mathrm{I}$ & $\rightarrow$ & $\mathrm{C}$ & 2 \\
$(6)$ & $\mathrm{S}$ & $\rightarrow$ & $\mathrm{I}$ & $\leftarrow$ & $\mathrm{C}$ & 14 \\
$(7)$ & $\mathrm{S}$ & $\rightarrow$ & $\mathrm{I}$ & $\leftrightarrow$ & $\mathrm{C}$ & 11 \\
$(8)$ & $\mathrm{S}$ & $\leftarrow$ & $\mathrm{I}$ & $\cdots$ & $\mathrm{C}$ & 3 \\
$(9)$ & $\mathrm{S}$ & $\leftarrow$ & $\mathrm{I}$ & $\rightarrow$ & $\mathrm{C}$ & 1 \\
$(10)$ & $\mathrm{S}$ & $\leftarrow$ & $\mathrm{I}$ & $\leftarrow$ & $\mathrm{C}$ & 3 \\
$(11)$ & $\mathrm{S}$ & $\leftarrow$ & $\mathrm{I}$ & $\leftrightarrow$ & $\mathrm{C}$ & 3 \\
$(12)$ & $\mathrm{S}$ & $\leftrightarrow$ & $\mathrm{I}$ & $\cdots$ & $\mathrm{C}$ & 0 \\
$(13)$ & $\mathrm{S}$ & $\leftrightarrow$ & $\mathrm{I}$ & $\rightarrow$ & $\mathrm{C}$ & 1 \\
$(14)$ & $\mathrm{S}$ & $\leftrightarrow$ & $\mathrm{I}$ & $\leftarrow$ & $\mathrm{C}$ & 5 \\
$(15)$ & $\mathrm{S}$ & $\leftrightarrow$ & $\mathrm{I}$ & $\leftrightarrow$ & $\mathrm{C}$ & 51 \\
\hline Number of & & \\
\hline
\end{tabular}

This table presents the statistics of the estimated volatility spillover coefficients between each of the 65 US industries and its representative supplier (Panel 1) and representative customer (Panel 2). The representative supplier of industry $i$ is constructed as the weighted-portfolio of all the industries selling goods or services to industry $i$. Each supplier industry receives a weight based on its share in total industry i's inputs. The weights are calculated from the elements in the column corresponding to industry $i$ in the SUPP matrix (2007 IO benchmark). The representative customer is constructed similarly based on the elements in the CUST matrix. The table reports the number of daily observations for each model, the minimum, maximum, and mean value of the estimated coefficients. The last two columns report the number and the percentage of estimated coefficients with t-statistics above 1.645 (10\% significance level).

Panel 3 details the direction of spillovers identified in Panels 1 and 2. Panel 4 considers the 15 possible combinations of volatility spillovers between an industry (I), its representative supplier (S) and its representative customer $(\mathrm{C})$. Arrows $(\rightarrow$ or $\leftarrow)$ show the direction of the volatility spillover, " $\leftrightarrow$ " means bidirectional volatility spillover, and "..." denotes no volatility spillover. For example, $(\mathrm{S} \leftarrow \mathrm{I} \rightarrow \mathrm{C})$ means the volatility of industry I affects the volatility of both its representative supplier $\mathrm{S}$ and representative customer $\mathrm{C}$, but not vice versa. The column reports the number of industries with significant spillovers (either GARCH or ARCH) for each combination. 
Table 8

Volatility spillovers and portfolio concentration

\begin{tabular}{|c|c|c|c|c|}
\hline & $\begin{array}{c}\text { (1) } \\
\text { SuppInd }\end{array}$ & $\begin{array}{c}(2) \\
\text { SuppInd }\end{array}$ & $\begin{array}{c}\text { (3) } \\
\text { CustInd }\end{array}$ & $\begin{array}{c}\text { (4) } \\
\text { CustInd }\end{array}$ \\
\hline Representative Supplier HHI concentration & $\begin{array}{c}-6.925^{* *} \\
(3.331)\end{array}$ & $\begin{array}{c}-9.071 * * \\
(3.977)\end{array}$ & & \\
\hline Industry size & & $\begin{array}{c}-0.001 * * \\
(0.000)\end{array}$ & & $\begin{array}{c}-0.001 * * \\
(0.000)\end{array}$ \\
\hline Industry concentration & & $\begin{array}{c}-1.560 * * * \\
(0.484)\end{array}$ & & $\begin{array}{c}-0.317 \\
(0.287)\end{array}$ \\
\hline Representative Customer HHI concentration & & & $\begin{array}{l}1.659 * \\
(0.983)\end{array}$ & $\begin{array}{c}0.151 \\
(1.206)\end{array}$ \\
\hline Observations & 65 & 56 & 65 & 56 \\
\hline Pseudo $\mathrm{R}^{2}$ & 0.0718 & 0.260 & 0.0281 & 0.106 \\
\hline Log likelihood & -40.20 & -27.01 & -35.26 & -26.02 \\
\hline
\end{tabular}

This table reports probit marginal effects and robust standard errors (in parentheses). The dichotomous dependent variables are SuppInd in columns 1-2 and CustInd in columns 3-4, respectively. SuppInd takes value 1 for significant volatility spillovers from the representative supplier to the industry as identified in Table 7 Panel 3, 0 otherwise. Similarly, CustInd is equal to 1 for significant volatility spillovers from the representative customer to the industry, 0 otherwise. The Herfindahl-Hirschman index (HHI) of the degree of concentration of the representative supplier / customer is calculated as the sum of the squared weights used to construct the respective portfolios. The IO data, industry size (millions of firms), and industry (eight firm) concentration ratios refer to year 2007. *,** and $* * *$ denote the $10 \%, 5 \%$ and $1 \%$ significance levels, respectively. 
Table 9

Business linkages and volatility spillover estimated from DCC-multivariate GARCH model

\begin{tabular}{|c|c|c|c|c|c|c|c|c|}
\hline & \multicolumn{4}{|c|}{ GARCH spillover } & \multicolumn{4}{|c|}{ ARCH spillover } \\
\hline & $(1)$ & $(2)$ & $(3)$ & (4) & $(5)$ & $(6)$ & $(7)$ & $(8)$ \\
\hline $\begin{array}{l}\text { Customer role of Industry } \\
\left(C U S T_{j i}\right)\end{array}$ & $\begin{array}{c}1.305 \\
(1.101)\end{array}$ & $\begin{array}{c}1.182 \\
(1.258)\end{array}$ & $\begin{array}{l}3.475 \\
(2.705)\end{array}$ & $\begin{array}{c}2.927 \\
(2.732)\end{array}$ & $\begin{array}{l}0.268^{*} \\
(0.149)\end{array}$ & $\begin{array}{c}0.148 \\
(0.178)\end{array}$ & $\begin{array}{l}0.506^{*} \\
(0.294)\end{array}$ & $\begin{array}{c}0.324 \\
(0.305)\end{array}$ \\
\hline $\begin{array}{l}\text { Supplier role of Industry } \\
\left(S U P P_{i j}\right)\end{array}$ & $\begin{array}{c}0.582 \\
(0.514)\end{array}$ & $\begin{array}{c}0.515 \\
(0.517)\end{array}$ & $\begin{array}{c}0.772 \\
(0.848)\end{array}$ & $\begin{array}{c}0.409 \\
(0.825)\end{array}$ & $\begin{array}{l}0.629 * \\
(0.335)\end{array}$ & $\begin{array}{l}0.581^{*} \\
(0.326)\end{array}$ & $\begin{array}{c}1.178 * * * \\
(0.375)\end{array}$ & $\begin{array}{c}1.032 * * * \\
(0.325)\end{array}$ \\
\hline $\begin{array}{l}\text { Customer role of Partner } \\
\left(C U S T_{i j}\right)\end{array}$ & $\begin{array}{c}-0.964 * * * \\
(0.309)\end{array}$ & $\begin{array}{c}-1.012 * * * \\
(0.309)\end{array}$ & $\begin{array}{c}-1.776 * * \\
(0.694)\end{array}$ & $\begin{array}{c}-1.196 * * \\
(0.593)\end{array}$ & $\begin{array}{c}-0.489 * * * \\
(0.177)\end{array}$ & $\begin{array}{c}-0.492 * * * \\
(0.179)\end{array}$ & $\begin{array}{c}-1.014 * * * \\
(0.352)\end{array}$ & $\begin{array}{c}-0.827 * * * \\
(0.291)\end{array}$ \\
\hline $\begin{array}{l}\text { Supplier role of Partner } \\
\left(S U P P_{j i}\right)\end{array}$ & $\begin{array}{l}-2.062 * * \\
(0.990)\end{array}$ & $\begin{array}{l}-2.092 * \\
(1.105)\end{array}$ & $\begin{array}{c}-4.904 * * * \\
(1.344)\end{array}$ & $\begin{array}{c}-4.211 * * * \\
(1.325)\end{array}$ & $\begin{array}{l}-0.518 * * \\
(0.210)\end{array}$ & $\begin{array}{c}-0.486^{* *} \\
(0.224)\end{array}$ & $\begin{array}{c}-1.126^{* * *} \\
(0.219)\end{array}$ & $\begin{array}{c}-0.926 * * * \\
(0.187)\end{array}$ \\
\hline Industry Size & & $\begin{array}{c}0.022 \\
(0.079)\end{array}$ & & $\begin{array}{c}0.090 \\
(0.144)\end{array}$ & & $\begin{array}{c}0.036 \\
(0.033)\end{array}$ & & $\begin{array}{c}0.051 \\
(0.046)\end{array}$ \\
\hline Partner Size & & $\begin{array}{l}-0.052 \\
(0.032)\end{array}$ & & $\begin{array}{c}-0.354 * * * \\
(0.054)\end{array}$ & & $\begin{array}{l}-0.014 \\
(0.011)\end{array}$ & & $\begin{array}{c}-0.094 * * * \\
(0.016)\end{array}$ \\
\hline Industry Concentration & & & $\begin{array}{l}-0.034 \\
(0.063)\end{array}$ & $\begin{array}{l}-0.008 \\
(0.082)\end{array}$ & & & $\begin{array}{l}-0.030 \\
(0.033)\end{array}$ & $\begin{array}{l}-0.015 \\
(0.028)\end{array}$ \\
\hline Partner Concentration & & & $\begin{array}{c}-0.608 * * * \\
(0.082)\end{array}$ & $\begin{array}{c}-0.716^{* * *} \\
(0.091)\end{array}$ & & & $\begin{array}{c}-0.146^{* * *} \\
(0.032)\end{array}$ & $\begin{array}{c}-0.174 * * * \\
(0.034)\end{array}$ \\
\hline Observations & 4,160 & 3,906 & 3,080 & 3,080 & 4,160 & 3,906 & 3,080 & 3,080 \\
\hline Adjusted $\mathrm{R}^{2}$ & 0.002 & 0.002 & 0.022 & 0.024 & 0.002 & 0.002 & 0.011 & 0.012 \\
\hline
\end{tabular}

This table reports cross-sectional estimated coefficients and bootstrapped standard errors (in parentheses). The dependent variables are the GARCH spillover and the ARCH spillover coefficients obtained from the DCC-multivariate GARCH model using daily returns over the period 1 January 2005 - 31 December 2013 . The relation between the two volatility spillover coefficients and the business linkage variables are specified in Eqs. (8) and (9). The business linkage variables, industry size (millions of firms) and the concentration ratios refer to year $2007 . * * *$ and $* * *$ denote the $10 \%, 5 \%$ and $1 \%$ significance levels, respectively. 
Appendix A. Input-Output Accounts and Constructed Tables

Table A.1. MAKE Table (2007)

(Millions of dollars)

\begin{tabular}{|c|c|c|c|c|c|c|c|c|c|}
\hline & Industries/Commodities & 111CA & 113FF & 211 & $\ldots$ & GSLE & Used & Other & \\
\hline $\begin{array}{c}\text { IO } \\
\text { Code } \\
\end{array}$ & Name & Farms & $\begin{array}{c}\text { Forestry, } \\
\text { fishing, and } \\
\text { related } \\
\text { activities } \\
\end{array}$ & $\begin{array}{c}\text { Oil and gas } \\
\text { extraction }\end{array}$ & $\ldots$ & $\begin{array}{c}\text { State and } \\
\text { local } \\
\text { governmen } \\
\mathbf{t} \\
\text { enterprises } \\
\end{array}$ & $\begin{array}{c}\text { Scrap, used } \\
\text { and } \\
\text { second- } \\
\text { hand goods } \\
\end{array}$ & $\begin{array}{c}\text { Noncomparabl } \\
\text { e imports and } \\
\text { rest-of-the- } \\
\text { world } \\
\text { adjustment } \\
\end{array}$ & $\begin{array}{c}\text { Total } \\
\text { Industry } \\
\text { Output } \\
\end{array}$ \\
\hline $111 \mathrm{CA}$ & Farms & 297412 & 3502 & 0 & $\ldots$ & 0 & 0 & 0 & 302485 \\
\hline $113 \mathrm{FF}$ & $\begin{array}{l}\text { Forestry, fishing, and related } \\
\text { activities }\end{array}$ & 15 & 44384 & 0 & $\ldots$ & 0 & 0 & 0 & 44457 \\
\hline 211 & Oil and gas extraction & 0 & 0 & 234820 & $\ldots$ & 0 & 0 & 0 & 293640 \\
\hline$\ldots$ & $\ldots$ & $\ldots$ & $\ldots$ & $\ldots$ & $\ldots$ & $\ldots$ & $\ldots$ & $\ldots$ & \\
\hline GFE & Federal government enterprises & 0 & 0 & 0 & $\ldots$ & 0 & 0 & 0 & 96005 \\
\hline GSLG & $\begin{array}{l}\text { State and local general } \\
\text { government }\end{array}$ & 463 & 2715 & 0 & $\ldots$ & 0 & 3796 & 0 & 1787992 \\
\hline GSLE & $\begin{array}{l}\text { State and local government } \\
\text { enterprises }\end{array}$ & 0 & 0 & 0 & $\ldots$ & 67345 & 0 & 0 & 224087 \\
\hline & Total Commodity Output & 298058 & 51457 & 235813 & $\ldots$ & 68727 & 10223 & 1703 & 26151297 \\
\hline & Total Commodity Supply [1] & 322648 & 66696 & 516716 & $\ldots$ & 68727 & 124674 & 242784 & 28583161 \\
\hline
\end{tabular}

This table is extracted from the Make table (2007), provided by the Bureau of Economic Analysis (BEA), showing the make of 73 commodities by 71 industries in the US. Each industry is presented in a row and each commodity is shown in a column. Each entry documents the value of the commodity in the corresponding column produced by the industry in the corresponding row. The sum of all entries in a row is the Total Industry Output and the sum of all entries in a column is the Total Commodity Output.

[1] The Total Commodity Supply is added to this table, showing the actual total supply of the commodity in the corresponding column. This is equal to the total output of commodity c produced by all industries, which is the sum of all entries in the corresponding column of commodity c in the Make table, plus other components such as imports or changes in inventories which increase the actual supply of commodity to be used in the production of industries (or consumption of final users). 
Table A.2. USE Table (2007)

(Millions of dollars)

\begin{tabular}{|c|c|c|c|c|c|c|c|c|c|c|c|c|c|c|}
\hline & Commodities/Industries & 111CA & 113FF & 211 & $\ldots$ & GFE & GSLG & GSLE & & F010 & $\ldots$ & F10N & & \\
\hline $\begin{array}{c}\text { IO } \\
\text { Code }\end{array}$ & Name & Farms & $\begin{array}{c}\text { Forestry, } \\
\text { fishing, } \\
\text { and } \\
\text { related } \\
\text { activities }\end{array}$ & $\begin{array}{c}\text { Oil and } \\
\text { gas } \\
\text { extraction }\end{array}$ & $\ldots$ & $\begin{array}{c}\text { Federal } \\
\text { govern- } \\
\text { ment } \\
\text { enterprises }\end{array}$ & $\begin{array}{c}\text { State } \\
\text { and } \\
\text { local } \\
\text { general } \\
\text { govern- } \\
\text { ment } \\
\end{array}$ & $\begin{array}{c}\text { State and } \\
\text { local } \\
\text { govern- } \\
\text { ment } \\
\text { enterprises }\end{array}$ & $\begin{array}{c}\text { Total } \\
\text { Intermediate }\end{array}$ & $\begin{array}{l}\text { Personal } \\
\text { consump- } \\
\text { tion } \\
\text { expendi- } \\
\text { tures }\end{array}$ & $\ldots$ & $\begin{array}{c}\text { State and } \\
\text { local: } \\
\text { Gross } \\
\text { investment } \\
\text { in } \\
\text { intellectual } \\
\text { property } \\
\text { products } \\
\end{array}$ & $\begin{array}{l}\text { Total } \\
\text { Final } \\
\text { Uses } \\
\text { (GDP) } \\
\end{array}$ & $\begin{array}{c}\text { Total } \\
\text { Commodity } \\
\text { Output }\end{array}$ \\
\hline $111 \mathrm{CA}$ & Farms & 45189 & 637 & 0 & $\ldots$ & 2 & 2088 & 0 & 231705 & 52756 & $\ldots$ & 0 & 66354 & 298058 \\
\hline $113 \mathrm{FF}$ & $\begin{array}{l}\text { Forestry, fishing, and } \\
\text { related activities }\end{array}$ & 19526 & 5785 & 0 & $\ldots$ & 4 & 1228 & 0 & 56330 & 5424 & $\ldots$ & 0 & -4872 & 51457 \\
\hline 211 & Oil and gas extraction & 0 & 0 & 38347 & $\ldots$ & 846 & 0 & 11949 & 509219 & 0 & $\ldots$ & 0 & -273406 & 235813 \\
\hline$\ldots$ & $\ldots$ & $\ldots$ & $\ldots$ & $\ldots$ & $\ldots$ & $\ldots$ & $\ldots$ & $\ldots$ & $\ldots$ & $\ldots$ & $\ldots$ & $\ldots$ & $\ldots$ & $\ldots$ \\
\hline GSLE & $\begin{array}{l}\text { State and local } \\
\text { government enterprises }\end{array}$ & 0 & 4 & 0 & $\ldots$ & 253 & 3236 & 643 & 18111 & 50615 & $\ldots$ & 0 & 50615 & 68727 \\
\hline Used & $\begin{array}{l}\text { Scrap, used and second- } \\
\text { hand goods }\end{array}$ & 0 & 1 & 0 & $\ldots$ & 0 & 0 & 0 & 22312 & 67057 & $\ldots$ & 0 & -12089 & 10223 \\
\hline Other & $\begin{array}{l}\text { Noncomparable imports } \\
\text { and rest-of-the-world } \\
\text { adjustment }\end{array}$ & 592 & 46 & 712 & $\ldots$ & 946 & 0 & 0 & 111725 & -48866 & $\ldots$ & 0 & -110022 & 1703 \\
\hline & Total Intermediate & 188952 & 15991 & 88353 & $\ldots$ & 29944 & 577797 & 131386 & 11673662 & 0 & $\ldots$ & 0 & 0 & 0 \\
\hline V001 & $\begin{array}{l}\text { Compensation of } \\
\text { employees }\end{array}$ & 25013 & 16486 & 22573 & $\ldots$ & 60988 & 1065499 & 84938 & 7908768 & 0 & $\ldots$ & 0 & 0 & 0 \\
\hline V002 & $\begin{array}{l}\text { Taxes on production and } \\
\text { imports, less subsidies }\end{array}$ & -3878 & 1353 & 27024 & 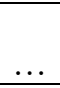 & -3044 & 0 & -15629 & 979978 & 0 & & 0 & 0 & 0 \\
\hline \multirow[t]{3}{*}{ V003 } & Gross operating surplus & 92398 & 10628 & 155691 & $\ldots$ & 8118 & 144696 & 23392 & 5588888 & 0 & $\ldots$ & 0 & 0 & 0 \\
\hline & Total Value Added & 113534 & 28466 & 205288 & $\ldots$ & 66061 & 1210195 & 92701 & 0 & 0 & $\ldots$ & 0 & 14477634 & 0 \\
\hline & Total Industry Output & 302485 & 44457 & 293640 & $\ldots$ & 96005 & 1787992 & 224087 & 0 & 9750504 & $\ldots$ & 25758 & 0 & 26151297 \\
\hline
\end{tabular}

This table is extracted from the Use table (2007), provided by the Bureau of Economic Analysis (BEA), showing the use of 73 commodities by 71 industries and Final users in the US. Each commodity is displayed in a row and each industry is presented in a column. Each entry documents the value of the commodity in the corresponding row that the industry in the corresponding column uses as the input for its production. The sum of all entries in a row is the Total Commodity Output and the sum of all entries in a column is the Total Industry Output. 
Table A.3. SHARE Table (2007)

\begin{tabular}{|c|c|c|c|c|c|c|c|c|}
\hline & Industries/Commodities & 111CA & 113FF & 211 & $\ldots$ & GSLE & Used & Other \\
\hline $\begin{array}{c}\text { IO } \\
\text { Code }\end{array}$ & Name & Farms & $\begin{array}{c}\text { Forestry, } \\
\text { fishing, and } \\
\text { related } \\
\text { activities }\end{array}$ & $\begin{array}{l}\text { Oil and gas } \\
\text { extraction }\end{array}$ & $\ldots$ & $\begin{array}{c}\text { State and } \\
\text { local } \\
\text { government } \\
\text { enterprises }\end{array}$ & $\begin{array}{l}\text { Scrap, used } \\
\text { and second- } \\
\text { hand goods }\end{array}$ & $\begin{array}{l}\text { Noncomparable } \\
\text { imports and } \\
\text { rest-of-the- } \\
\text { world } \\
\text { adjustment }\end{array}$ \\
\hline $111 \mathrm{CA}$ & Farms & $92.18 \%$ & $5.25 \%$ & $0.00 \%$ & $\ldots$ & $0.00 \%$ & $0.00 \%$ & $0.00 \%$ \\
\hline $113 \mathrm{FF}$ & $\begin{array}{l}\text { Forestry, fishing, and related } \\
\text { activities }\end{array}$ & $0.00 \%$ & $66.55 \%$ & $0.00 \%$ & $\ldots$ & $0.00 \%$ & $0.00 \%$ & $0.00 \%$ \\
\hline 211 & Oil and gas extraction & $0.00 \%$ & $0.00 \%$ & $45.44 \%$ & $\ldots$ & $0.00 \%$ & $0.00 \%$ & $0.00 \%$ \\
\hline & $\ldots$ & & & & $\ldots$ & & & \\
\hline GFE & Federal government enterprises & $0.00 \%$ & $0.00 \%$ & $0.00 \%$ & $\ldots$ & $0.00 \%$ & $0.00 \%$ & $0.00 \%$ \\
\hline GSLG & $\begin{array}{l}\text { State and local general } \\
\text { government }\end{array}$ & $0.14 \%$ & $4.07 \%$ & $0.00 \%$ & $\ldots$ & $0.00 \%$ & $3.04 \%$ & $0.00 \%$ \\
\hline GSLE & $\begin{array}{l}\text { State and local government } \\
\text { enterprises }\end{array}$ & $0.00 \%$ & $0.00 \%$ & $0.00 \%$ & & $97.99 \%$ & $0.00 \%$ & $0.00 \%$ \\
\hline
\end{tabular}

This table is extracted from the constructed SHARE table (2007), demonstrating the proportion of the commodity supplies that each industry accounts for. Each industry is presented in a row and each commodity is shown in a column. Each entry displays the percentage of the total supply of the commodity in the corresponding column produced by the industry in the corresponding row. 
Table A.4. REVSHARE Table (2007)

(Millions of dollars)

\begin{tabular}{|c|c|c|c|c|c|c|c|c|}
\hline & Industries/Commodities & 111CA & 113FF & 211 & $\ldots$ & GFE & GSLG & GSLE \\
\hline IOCode & Name & Farms & $\begin{array}{c}\text { Forestry, } \\
\text { fishing, and } \\
\text { related } \\
\text { activities }\end{array}$ & $\begin{array}{c}\text { Oil and gas } \\
\text { extraction }\end{array}$ & $\ldots$ & $\begin{array}{c}\text { Federal } \\
\text { government } \\
\text { enterprises }\end{array}$ & $\begin{array}{c}\text { State and } \\
\text { local } \\
\text { general } \\
\text { government } \\
\end{array}$ & $\begin{array}{c}\begin{array}{c}\text { State and } \\
\text { local } \\
\text { government } \\
\text { enterprises }\end{array} \\
\end{array}$ \\
\hline $111 \mathrm{CA}$ & Farms & 42681 & 891 & 0 & $\ldots$ & 2 & 1999 & 2 \\
\hline $113 \mathrm{FF}$ & $\begin{array}{l}\text { Forestry, fishing, and related } \\
\text { activities }\end{array}$ & 12996 & 3850 & 0 & $\ldots$ & 3 & 818 & 1 \\
\hline 211 & Oil and gas extraction & 477 & 38 & 19149 & $\ldots$ & 471 & 2534 & 5793 \\
\hline$\ldots$ & $\ldots$ & $\ldots$ & $\ldots$ & $\ldots$ & $\ldots$ & $\ldots$ & $\ldots$ & $\ldots$ \\
\hline GFE & Federal government enterprises & 168 & 9 & 53 & $\ldots$ & 47 & 3356 & 191 \\
\hline GSLG & $\begin{array}{l}\text { State and local general } \\
\text { government }\end{array}$ & 1069 & 278 & 176 & $\ldots$ & 241 & 7719 & 1314 \\
\hline GSLE & $\begin{array}{l}\text { State and local government } \\
\text { enterprises }\end{array}$ & 851 & 35 & 361 & & 582 & 9432 & 1068 \\
\hline
\end{tabular}

This table is extracted from the constructed REVSHARE table (2007), showing the value of goods traded between any pairs of industries in the US. The element of row $i$, column $j\left(\right.$ REVSHARE $\left._{i j}\right)$ demonstrates the total value of the goods flowing from industry $i$ to industry $j$ (i.e. the total value of all commodities that industry $j$ buys from industry $i$, or the revenue industry $j$ generates for industry $i$ ). 
Table A.5. CUST Table (2007)

\begin{tabular}{|c|c|c|c|c|c|c|c|c|}
\hline & Industries/Commodities & 111CA & 113FF & 211 & $\ldots$ & GFE & GSLG & GSLE \\
\hline $\begin{array}{c}\text { IO } \\
\text { Code }\end{array}$ & Name & Farms & $\begin{array}{c}\text { Forestry, } \\
\text { fishing, and } \\
\text { related } \\
\text { activities }\end{array}$ & $\begin{array}{l}\text { Oil and gas } \\
\text { extraction }\end{array}$ & $\ldots$ & $\begin{array}{c}\text { Federal } \\
\text { government } \\
\text { enterprises }\end{array}$ & $\begin{array}{c}\text { State and } \\
\text { local } \\
\text { general } \\
\text { government }\end{array}$ & $\begin{array}{c}\begin{array}{c}\text { State and } \\
\text { local }\end{array} \\
\text { government } \\
\text { enterprises }\end{array}$ \\
\hline $111 \mathrm{CA}$ & Farms & 0.141 & 0.003 & 0.000 & $\ldots$ & 0.000 & 0.007 & 0.000 \\
\hline $113 \mathrm{FF}$ & $\begin{array}{l}\text { Forestry, fishing, and related } \\
\text { activities }\end{array}$ & 0.292 & 0.087 & 0.000 & $\ldots$ & 0.000 & 0.018 & 0.000 \\
\hline 211 & Oil and gas extraction & 0.002 & 0.000 & 0.065 & $\ldots$ & 0.002 & 0.009 & 0.020 \\
\hline$\ldots$ & $\ldots$ & & & & $\ldots$ & & & \\
\hline GFE & Federal government enterprises & 0.002 & 0.000 & 0.001 & $\ldots$ & 0.000 & 0.035 & 0.002 \\
\hline GSLG & $\begin{array}{l}\text { State and local general } \\
\text { government }\end{array}$ & 0.001 & 0.000 & 0.000 & $\cdots$ & 0.000 & 0.004 & 0.001 \\
\hline GSLE & $\begin{array}{l}\text { State and local government } \\
\text { enterprises }\end{array}$ & 0.004 & 0.000 & 0.002 & & 0.003 & 0.042 & 0.005 \\
\hline
\end{tabular}

This table is extracted from the constructed CUST table (2007), showing the importance of the role of an industry as the customer of the other industry. The element of row $i$ and column $j\left(C U S T_{i j}\right)$ demonstrates the role of industry $j$ in the customer profile of industry $i$ (i.e., the proportion of the revenue of industry $i$ that is generated by industry $j$ ). 
Table A.6. SUPP Table (2007)

\begin{tabular}{|c|c|c|c|c|c|c|c|c|}
\hline & Industries/Commodities & 111CA & 113FF & 211 & $\ldots$ & GFE & GSLG & GSLE \\
\hline $\begin{array}{c}\text { IO } \\
\text { Code }\end{array}$ & Name & Farms & $\begin{array}{c}\text { Forestry, } \\
\text { fishing, and } \\
\text { related } \\
\text { activities }\end{array}$ & $\begin{array}{l}\text { Oil and gas } \\
\text { extraction }\end{array}$ & $\ldots$ & $\begin{array}{c}\text { Federal } \\
\text { government } \\
\text { enterprises }\end{array}$ & $\begin{array}{c}\text { State and } \\
\text { local } \\
\text { general } \\
\text { government }\end{array}$ & $\begin{array}{c}\begin{array}{c}\text { State and } \\
\text { local }\end{array} \\
\text { government } \\
\text { enterprises }\end{array}$ \\
\hline $111 \mathrm{CA}$ & Farms & 0.199 & 0.027 & 0.000 & $\ldots$ & 0.000 & 0.001 & 0.000 \\
\hline $113 \mathrm{FF}$ & $\begin{array}{l}\text { Forestry, fishing, and related } \\
\text { activities }\end{array}$ & 0.061 & 0.119 & 0.000 & $\ldots$ & 0.000 & 0.000 & 0.000 \\
\hline 211 & Oil and gas extraction & 0.002 & 0.001 & 0.173 & $\ldots$ & 0.005 & 0.002 & 0.027 \\
\hline$\ldots$ & $\ldots$ & & & & $\ldots$ & & & \\
\hline GFE & Federal government enterprises & 0.001 & 0.000 & 0.000 & $\ldots$ & 0.001 & 0.002 & 0.001 \\
\hline GSLG & $\begin{array}{l}\text { State and local general } \\
\text { government }\end{array}$ & 0.005 & 0.009 & 0.002 & $\ldots$ & 0.003 & 0.005 & 0.006 \\
\hline GSLE & $\begin{array}{l}\text { State and local government } \\
\text { enterprises }\end{array}$ & 0.004 & 0.001 & 0.003 & & 0.006 & 0.006 & 0.005 \\
\hline
\end{tabular}

This table is extracted from the constructed SUPP table (2007), demonstrating the importance of an industry as the supplier of the other industry. The element of row $i$ and column $j\left(S U P P_{i j}\right)$ shows the role of industry $i$ in the supplier profile of industry $j$ (i.e., the proportion of the total input of industry $j$ that is purchased from industry $i$ ). 


\section{Appendix B}

Table B.1. Business linkages and volatility spillovers - controlling for the crisis period

\begin{tabular}{|c|c|c|c|c|c|c|c|c|}
\hline & \multicolumn{4}{|c|}{ GARCH spillover } & \multicolumn{4}{|c|}{ ARCH spillover } \\
\hline & (1) & (2) & (3) & (4) & (5) & (6) & (7) & (8) \\
\hline $\begin{array}{l}\text { Customer role of Industry } \\
\left(\text { CUST }_{j i}\right)\end{array}$ & $\begin{array}{c}1.826 \\
(1.300)\end{array}$ & $\begin{array}{c}1.653 \\
(1.422)\end{array}$ & $\begin{array}{c}4.929 \\
(3.271)\end{array}$ & $\begin{array}{c}4.167 \\
(3.158)\end{array}$ & $\begin{array}{l}0.254 * \\
(0.152)\end{array}$ & $\begin{array}{c}0.128 \\
(0.182)\end{array}$ & $\begin{array}{c}0.466 \\
(0.299)\end{array}$ & $\begin{array}{c}0.280 \\
(0.314)\end{array}$ \\
\hline $\begin{array}{l}\text { Supplier role of Industry } \\
\left(\operatorname{SUPP}_{i j}\right)\end{array}$ & $\begin{array}{c}1.022 \\
(0.839)\end{array}$ & $\begin{array}{c}0.876 \\
(0.792)\end{array}$ & $\begin{array}{c}1.656 \\
(1.217)\end{array}$ & $\begin{array}{c}1.004 \\
(1.014)\end{array}$ & $\begin{array}{l}0.652^{*} \\
(0.349)\end{array}$ & $\begin{array}{l}0.600 * \\
(0.337)\end{array}$ & $\begin{array}{c}1.228 * * * \\
(0.398)\end{array}$ & $\begin{array}{c}1.085^{* * *} \\
(0.343)\end{array}$ \\
\hline $\begin{array}{l}\text { Customer role of Partner } \\
\left(\text { CUST }_{i j}\right)\end{array}$ & $\begin{array}{c}-1.190 * * * \\
(0.454)\end{array}$ & $\begin{array}{c}-1.164 * * * \\
(0.433)\end{array}$ & $\begin{array}{c}-2.246^{* *} \\
(0.923)\end{array}$ & $\begin{array}{c}-1.471 * * \\
(0.709)\end{array}$ & $\begin{array}{c}-0.509 * * * \\
(0.186)\end{array}$ & $\begin{array}{c}-0.503 * * * \\
(0.187)\end{array}$ & $\begin{array}{c}-1.058^{* * * *} \\
(0.371)\end{array}$ & $\begin{array}{c}-0.865^{* * * *} \\
(0.307)\end{array}$ \\
\hline $\begin{array}{l}\text { Supplier role of Partner } \\
\left(S U P P_{j i}\right)\end{array}$ & $\begin{array}{c}-2.403 * * \\
(1.186)\end{array}$ & $\begin{array}{l}-2.371 * \\
(1.268)\end{array}$ & $\begin{array}{c}-5.638^{* * * *} \\
(1.633)\end{array}$ & $\begin{array}{c}-4.851 * * * \\
(1.561)\end{array}$ & $\begin{array}{c}-0.532 * * \\
(0.218)\end{array}$ & $\begin{array}{c}-0.495^{* *} \\
(0.230)\end{array}$ & $\begin{array}{c}-1.145^{* * * *} \\
(0.223)\end{array}$ & $\begin{array}{c}-0.934 * * * \\
(0.189)\end{array}$ \\
\hline Industry Size & & $\begin{array}{c}0.112 \\
(0.115)\end{array}$ & & $\begin{array}{c}0.248 \\
(0.198)\end{array}$ & & $\begin{array}{c}0.035 \\
(0.034)\end{array}$ & & $\begin{array}{c}0.047 \\
(0.047)\end{array}$ \\
\hline Partner Size & & $\begin{array}{c}-0.063 * * \\
(0.031)\end{array}$ & & $\begin{array}{c}-0.356 * * * \\
(0.053)\end{array}$ & & $\begin{array}{l}-0.019^{*} \\
(0.011)\end{array}$ & & $\begin{array}{c}-0.102^{* * * *} \\
(0.016)\end{array}$ \\
\hline Industry Concentration & & & $\begin{array}{l}-0.041 \\
(0.065)\end{array}$ & $\begin{array}{c}0.033 \\
(0.085)\end{array}$ & & & $\begin{array}{l}-0.034 \\
(0.035)\end{array}$ & $\begin{array}{l}-0.020 \\
(0.029)\end{array}$ \\
\hline Partner Concentration & & & $\begin{array}{c}-0.597 * * * \\
(0.083)\end{array}$ & $\begin{array}{c}-0.705^{* * *} \\
(0.091)\end{array}$ & & & $\begin{array}{c}-0.140^{* * * *} \\
(0.032)\end{array}$ & $\begin{array}{c}-0.171^{* * * *} \\
(0.035)\end{array}$ \\
\hline Observations & 4,160 & 3,906 & 3,080 & 3,080 & 4,160 & 3,906 & 3,080 & 3,080 \\
\hline Adjusted $\mathrm{R}^{2}$ & 0.003 & 0.003 & 0.020 & 0.023 & 0.002 & 0.002 & 0.010 & 0.011 \\
\hline
\end{tabular}

This table reports cross-sectional estimates and bootstrapped standard errors (in parentheses). The dependent variables are the GARCH spillover and the ARCH spillover coefficients obtained from the multivariate GARCH model (Eqs. (1)-(6)) using daily returns over the period 1 January 2005 - 31 December 2013 adding the crisis dummy variable in Eqs. (1) and (3). The relation between the two volatility spillover coefficients and the business linkage variables are specified in Eqs. (8) and (9). The business linkage variables, industry size (millions of firms) and the concentration ratios refer to year 2007 . *** and $* * *$ denote the $10 \%, 5 \%$ and $1 \%$ significance levels, respectively. 
Appendix C

Table C.1. The DCC - multivariate GARCH model - Summary statistics of estimates

\begin{tabular}{|c|c|c|c|c|c|c|}
\hline & Coefficients & Mean & Min & $\operatorname{Max}$ & $\begin{array}{l}\text { Number } \\
(t>1.645)\end{array}$ & $\%(t>1.645)$ \\
\hline$\alpha_{M 1}$ & Market return - Industry & 1.070 & 0.591 & 1.654 & 2080 & 100.00 \\
\hline$\alpha_{F X 1}$ & $\%$ change in FX index - Industry & 0.010 & -0.352 & 0.495 & 287 & 13.80 \\
\hline$\alpha_{\triangle R F 1}$ & Change in risk-free rate - Industry & -0.024 & -3.488 & 2.269 & 703 & 33.80 \\
\hline$\alpha_{M 2}$ & Market return - Partner & 1.057 & 0.558 & 1.674 & 2080 & 100.00 \\
\hline$\alpha_{F X 2}$ & $\%$ change in FX index - Partner & 0.012 & -0.335 & 0.420 & 260 & 12.50 \\
\hline$\alpha_{\triangle R F 2}$ & Change in risk-free rate - Partner & 0.006 & -3.091 & 2.620 & 682 & 32.79 \\
\hline$\alpha_{11}$ & Industry's return autocorrelation & 0.008 & -0.115 & 0.141 & 751 & 36.11 \\
\hline$\alpha_{22}$ & Partner's return autocorrelation & 0.012 & -0.137 & 0.135 & 761 & 36.59 \\
\hline$\alpha_{12}$ & Return spillover Partner-Industry & 0.006 & -0.098 & 0.237 & 493 & 23.70 \\
\hline$\alpha_{21}$ & Return spillover Industry-Partner & 0.008 & -0.208 & 0.212 & 573 & 27.55 \\
\hline$\beta_{11,1}$ & Industry's GARCH lag 1 & 0.430 & 0.000 & 0.991 & 1290 & 62.02 \\
\hline$\beta_{22,1}$ & Partner's GARCH lag 1 & 0.399 & 0.000 & 0.990 & 1298 & 62.40 \\
\hline$\gamma_{11,1}$ & Industry's ARCH lag 1 & 0.080 & 0.000 & 0.582 & 1993 & 95.82 \\
\hline$\gamma_{22,1}$ & Partner's ARCH lag 1 & 0.083 & 0.000 & 0.455 & 2019 & 97.07 \\
\hline$\beta_{11,2}$ & Industry's GARCH lag 2 & 0.513 & 0.000 & 0.970 & 1144 & $72.45^{*}$ \\
\hline$\beta_{22,2}$ & Partner's GARCH lag 2 & 0.502 & 0.000 & 0.974 & 1162 & $73.59 *$ \\
\hline$\gamma_{11,2}$ & Industry's ARCH lag 2 & 0.040 & 0.000 & 0.324 & 294 & $50.52 *$ \\
\hline$\gamma_{22,2}$ & Partner's ARCH lag 2 & 0.073 & 0.000 & 0.727 & 361 & $62.03 *$ \\
\hline
\end{tabular}




\begin{tabular}{|c|c|c|c|c|c|c|}
\hline & Coefficients & Mean & Min & Max & $\begin{array}{l}\text { Number } \\
(\mathrm{t}>1.645)\end{array}$ & $\%(t>1.645)$ \\
\hline$\beta_{12}$ & GARCH spillover Partner-Industry & 0.084 & 0.000 & 15.244 & 460 & 22.12 \\
\hline$\beta_{21}$ & GARCH spillover Industry-Partner & 0.216 & 0.000 & 13.749 & 604 & 29.04 \\
\hline$\gamma_{12}$ & ARCH spillover Partner-Industry & 0.031 & 0.000 & 2.643 & 788 & 37.88 \\
\hline$\gamma_{21}$ & ARCH spillover Industry-Partner & 0.068 & 0.000 & 10.714 & 875 & 42.07 \\
\hline
\end{tabular}

For each industry pair we use 2,264 daily observations to estimate the DCC-multivariate GARCH model specified by Eqs. (1)-(5) and (14)-(16).

$$
\begin{aligned}
& R_{i, t}=\alpha_{10}+\alpha_{M 1} R_{M t}+\alpha_{F X 1} F X_{t-1}+\alpha_{\Delta R F 1} \Delta R F_{t-1}+\alpha_{11} R_{i, t-1}+\alpha_{12} R_{j, t-1}+\varepsilon_{i, t} \\
& h_{i i, t}=\beta_{10}+\sum_{k=1}^{p} \beta_{11 k} h_{i i, t-k}+\sum_{l=1}^{q} \gamma_{11 l} \varepsilon_{i, t-l}^{2}+\beta_{12} h_{j j, t-1}+\gamma_{12} \varepsilon_{j, t-1}^{2} \\
& R_{j, t}=\alpha_{20}+\alpha_{M 2} R_{M t}+\alpha_{F X 2} F X_{t-1}+\alpha_{\Delta R F 2} \Delta R F_{t-1}+\alpha_{22} R_{j, t-1}+\alpha_{21} R_{i, t-1}+\varepsilon_{j, t} \\
& h_{j j, t}=\beta_{20}+\sum_{k=1}^{p} \beta_{22 k} h_{j j, t-k}+\sum_{l=1}^{q} \gamma_{22 l} \varepsilon_{j, t-l}^{2}+\beta_{21} h_{i i, t-1}+\gamma_{21} \varepsilon_{i, t-1}^{2} \\
& \varepsilon_{i, t}\left|\Omega_{t-1} \sim N\left(0, h_{i i, t}\right) ; \varepsilon_{j, t}\right| \Omega_{t-1} \sim N\left(0, h_{j j, t}\right) \\
& h_{i j, t}=\rho_{i j, t} \sqrt{h_{i i, t} h_{j j, t}}, i \neq j
\end{aligned}
$$

where

$$
\begin{aligned}
\rho_{i j, t} & =\frac{q_{i j, t}}{\sqrt{q_{i i, t} q_{j j, t}}} \\
q_{i j, t} & =\overline{\rho_{l \jmath}}+\omega_{1}\left(u_{i, t-1} u_{j, t-1}-\overline{\rho_{l \jmath}}\right)+\omega_{2}\left(q_{i j, t-1}-\overline{\rho_{l \jmath}}\right)
\end{aligned}
$$

The table reports the mean, the minimum, and the maximum value of the estimated coefficients for the 2,080 industry pairs; the number and percentage of estimated coefficients with t-statistics above 1.645 (10\% significance level). For each industry pair, the statistics refer to the best fitting model.

* These statistics are based on the number of best-fitting models which include the lags as shown below. For example, the coefficient of industry's GARCH lag 2 is statistically significant for 1,144 industry pairs among the 1,579 best-fitting $\operatorname{GARCH}(2,1)$ and $\operatorname{GARCH}(2,2)$ models $(72.45 \%)$.

$\begin{array}{lr}\text { Model } & \text { Number of best-fitting models } \\ \text { GARCH }(1,1) & 398 \\ \text { GARCH }(2,1) & 1,100 \\ \text { GARCH }(1,2) & 103 \\ \text { GARCH }(2,2) & 479\end{array}$




\section{Appendix D. Trivariate GARCH model}

We use a trivariate GARCH to account for the impact of all other industries in the first stage volatility spillovers. The model is specified as follows:

$$
\begin{aligned}
& R_{i, t}=\alpha_{10}+\alpha_{F X 1} F X_{t-1}+\alpha_{\Delta R F 1} \Delta R F_{t-1}+\alpha_{11} R_{i, t-1}+\alpha_{12} R_{j, t-1}+\alpha_{13} R_{O, t-1}+\varepsilon_{i, t} \\
& h_{i i, t}=\beta_{10}+\beta_{11} h_{i i, t-1}+\gamma_{11} \varepsilon_{i, t-1}^{2}+\beta_{12} h_{j j, t-1}+\gamma_{12} \varepsilon_{j, t-1}^{2}+\beta_{13} h_{O O, t-1}+\gamma_{13} \varepsilon_{O, t-1}^{2} \\
& R_{j, t}=\alpha_{20}+\alpha_{F X 2} F X_{t-1}+\alpha_{\Delta R F 2} \Delta R F_{t-1}+\alpha_{22} R_{j, t-1}+\alpha_{21} R_{i, t-1}+\alpha_{23} R_{O, t-1}+\varepsilon_{j, t} \\
& h_{j j, t}=\beta_{20}+\beta_{22} h_{j j, t-1}+\gamma_{22} \varepsilon_{j, t-l}^{2}+\beta_{21} h_{i i, t-1}+\gamma_{21} \varepsilon_{i, t-1}^{2}+\beta_{23} h_{O O, t-1}+\gamma_{23} \varepsilon_{O, t-1}^{2} \\
& R_{O, t}=\alpha_{30}+\alpha_{F X 3} F X_{t-1}+\alpha_{\Delta R F 3} \Delta R F_{t-1}+\alpha_{33} R_{O, t-1}+\alpha_{31} R_{i, t-1}+\alpha_{32} R_{j, t-1}+\varepsilon_{O, t} \\
& h_{O O, t}=\beta_{30}+\beta_{33} h_{O O, t-1}+\gamma_{33} \varepsilon_{O, t-1}^{2}+\beta_{31} h_{i i, t-1}+\gamma_{31} \varepsilon_{i, t-1}^{2}+\beta_{32} h_{j j, t-1}+\gamma_{32} \varepsilon_{j, t-1}^{2} \\
& \varepsilon_{i, t}\left|\Omega_{t-1} \sim N\left(0, h_{i i, t}\right) ; \varepsilon_{j, t}\right| \Omega_{t-1} \sim N\left(0, h_{j j, t}\right) ; \varepsilon_{O, t} \mid \Omega_{t-1} \sim N\left(0, h_{O O, t}\right) \\
& h_{i j, t}=\rho_{i j} \sqrt{h_{i i, t} h_{j j, t}}, h_{i O, t}=\rho_{i o} \sqrt{h_{i i, t} h_{O O, t}}, h_{j o, t}=\rho_{j o} \sqrt{h_{j j, t} h_{O O, t}},
\end{aligned}
$$

where $R$ stands for the excess returns, $i$ and $j$ index industries $(i, j=1,2, \ldots, 65 ; i \neq j), O$ stands for other partners, $O \neq i \neq j ; t$ denotes the time period. $F X$ and $\Delta R F$ are the percentage change in the foreign exchange rate index, and the change in the short-term interest rate, respectively; $\varepsilon_{i}, \varepsilon_{j}, \varepsilon_{O}$ are the error terms. At time $t$, the residual vector $\boldsymbol{\varepsilon}_{t}=\left(\varepsilon_{i, t}, \varepsilon_{j, t}, \varepsilon_{O, t}\right)$ follows $N\left(0, \mathbf{H}_{\mathrm{t}}\right)$ where

$$
\mathbf{H}_{\mathrm{t}}=\left[\begin{array}{lll}
h_{i i, t} & h_{i j, t} & h_{i o, t} \\
h_{j i, t} & h_{j j, t} & h_{j o, t} \\
h_{O i, t} & h_{O j, t} & h_{o o, t}
\end{array}\right]
$$

The parameter estimates in Eqs. (D.1) - (D.8) are obtained by maximizing the following log likelihood function:

$$
\mathrm{LL}=\sum_{t=1}^{T}\left(-\frac{1}{2}\left[2 \ln (2 \pi)+\ln \left|\mathbf{H}_{\mathrm{t}}\right|+\boldsymbol{\varepsilon}_{t}^{\prime} \mathbf{H}_{t}^{-1} \boldsymbol{\varepsilon}_{t}\right]\right),
$$

where $T$ is the number of trading days in our sample.

Due to heavy parameterization, we include the industry's own return and volatility at one lag only. To ensure that the estimates of variance are non-negative and that the volatility process is stationarity (i.e., the existence of constant long term volatility), we impose the following restrictions: all the $\beta$ and $\gamma$ coefficients in Eqs. (D.2), (D.4) and (D.6) are positive; $\left(\beta_{11}+\gamma_{11}\right)<1 ;\left(\beta_{22}+\gamma_{22}\right)<1$; $\left(\beta_{33}+\gamma_{33}\right)<1$; finally, the correlation coefficients lie in the interval $(-1,1)$. 
Table D.1. Business linkages and volatility spillover estimated from the trivariate GARCH model

\begin{tabular}{|c|c|c|c|c|c|c|c|c|}
\hline & \multicolumn{4}{|c|}{ GARCH spillover } & \multicolumn{4}{|c|}{ ARCH spillover } \\
\hline & $(1)$ & $(2)$ & $(3)$ & (4) & $(5)$ & $(6)$ & $(7)$ & $(8)$ \\
\hline Customer role of Industry & 0.195 & 0.226 & $0.628 *$ & $0.569^{*}$ & 0.046 & 0.041 & 0.103 & 0.085 \\
\hline$\left(C U S T_{j i}\right)$ & $(0.125)$ & $(0.155)$ & $(0.330)$ & $(0.325)$ & $(0.034)$ & $(0.035)$ & $(0.064)$ & $(0.066)$ \\
\hline Supplier role of Industry & 0.010 & 0.007 & -0.021 & -0.060 & 0.030 & 0.032 & 0.051 & 0.047 \\
\hline$\left(S U P P_{i j}\right)$ & $(0.076)$ & $(0.083)$ & $(0.152)$ & $(0.154)$ & $(0.036)$ & $(0.037)$ & $(0.057)$ & $(0.058)$ \\
\hline Customer role of Partner & $-0.119 * *$ & $-0.130 * *$ & $-0.242 * *$ & $-0.180 *$ & $-0.042 * *$ & $-0.053 * *$ & $-0.091 * *$ & $-0.070 *$ \\
\hline$\left(C U S T_{i j}\right)$ & $(0.054)$ & $(0.053)$ & $(0.114)$ & $(0.102)$ & $(0.021)$ & $(0.022)$ & $(0.042)$ & $(0.041)$ \\
\hline Supplier role of Partner & $-0.268 * *$ & $-0.270 * *$ & $-0.617 * * *$ & $-0.543 * * *$ & $-0.105^{* *}$ & $-0.109 * *$ & $-0.235^{* * *}$ & $-0.202 * * *$ \\
\hline$\left(S U P P_{j i}\right)$ & $(0.114)$ & $(0.124)$ & $(0.150)$ & $(0.141)$ & $(0.042)$ & $(0.048)$ & $(0.044)$ & $(0.042)$ \\
\hline \multirow[t]{2}{*}{ Industry Size } & & -0.004 & & 0.009 & & $-0.006^{*}$ & & -0.004 \\
\hline & & $(0.014)$ & & $(0.023)$ & & $(0.004)$ & & $(0.006)$ \\
\hline \multirow[t]{2}{*}{ Partner Size } & & $-0.017 * * *$ & & $-0.038 * * *$ & & $-0.004 * *$ & & $-0.019 * * *$ \\
\hline & & $(0.006)$ & & $(0.011)$ & & $(0.002)$ & & $(0.003)$ \\
\hline \multirow[t]{2}{*}{ Industry Concentration } & & & 0.014 & 0.016 & & & 0.006 & 0.005 \\
\hline & & & & $(0.014)$ & & & & $(0.005)$ \\
\hline \multirow[t]{2}{*}{ Partner Concentration } & & & $-0.031 * * *$ & $-0.043 * * *$ & & & $-0.030 * * *$ & $-0.035 * * *$ \\
\hline & & & $(0.011)$ & $(0.013)$ & & & $(0.005)$ & $(0.005)$ \\
\hline Observations & 4,160 & 3,906 & 3,080 & 3,080 & 4,160 & 3,906 & 3,080 & 3,080 \\
\hline Adjusted $\mathrm{R}^{2}$ & 0.001 & 0.001 & 0.004 & 0.005 & 0.002 & 0.002 & 0.016 & 0.018 \\
\hline
\end{tabular}

This table reports cross-sectional estimated coefficients and bootstrapped standard errors (in parentheses). The dependent variables are the GARCH spillover and the ARCH spillover coefficients obtained from the trivariate GARCH model using daily returns over the period 1 January 2005 - 31 December 2013 . The relation between the two volatility spillover coefficients and the business linkage variables are specified in Eqs. (8) and (9). The business linkage variables, industry size (millions of firms) and the concentration ratios refer to year $2007 . * * *$ and $* * *$ denote the $10 \%, 5 \%$ and $1 \%$ significance levels, respectively. 


\section{Appendix E}

Table E.1. Industry linkage variables calculated based on alternative Input-Output matrices

Panel 1. The business linkage variables and the industry size (millions of firms) refer to year 2005

\begin{tabular}{|c|c|c|c|c|}
\hline & \multicolumn{2}{|c|}{ GARCH spillover } & \multicolumn{2}{|c|}{ ARCH spillover } \\
\hline & (1) & $(2)$ & (3) & (4) \\
\hline Customer role of Industry & 1.428 & 1.282 & $0.260 *$ & 0.127 \\
\hline$\left(C U S T_{j i}\right)$ & $(1.179)$ & $(1.336)$ & $(0.155)$ & $(0.186)$ \\
\hline Supplier role of Industry & 0.481 & 0.417 & $0.686^{*}$ & $0.634 *$ \\
\hline$\left(S U P P_{i j}\right)$ & $(0.511)$ & $(0.507)$ & $(0.373)$ & $(0.356)$ \\
\hline Customer role of Partner & $-0.911 * * *$ & $-0.954 * * *$ & $-0.517 * * *$ & $-0.517 * * *$ \\
\hline$\left(C U S T_{i j}\right)$ & $(0.314)$ & $(0.306)$ & $(0.197)$ & $(0.197)$ \\
\hline Supplier role of Partner & $-2.268 * *$ & $-2.275^{* *}$ & $-0.554 * * *$ & $-0.514 * *$ \\
\hline$\left(S U P P_{j i}\right)$ & $(1.050)$ & $(1.151)$ & $(0.213)$ & $(0.221)$ \\
\hline \multirow[t]{2}{*}{ Industry Size } & & 0.026 & & 0.036 \\
\hline & & $(0.082)$ & & $(0.034)$ \\
\hline \multirow[t]{2}{*}{ Partner Size } & & -0.045 & & -0.012 \\
\hline & & $(0.031)$ & & $(0.011)$ \\
\hline Observations & 4,160 & 3,906 & 4,160 & 3,906 \\
\hline Adjusted $\mathrm{R}^{2}$ & 0.003 & 0.003 & 0.003 & 0.002 \\
\hline
\end{tabular}

Panel 2. The business linkage variables and the industry size (millions of firms) refer to year 2006

\begin{tabular}{|c|c|c|c|c|}
\hline & GAR & llover & $\mathrm{ARC}$ & lover \\
\hline & $(1)$ & $(2)$ & $(3)$ & $(4)$ \\
\hline Customer role of Industry & 1.366 & 1.217 & $0.261 *$ & 0.135 \\
\hline$\left(C U S T_{j i}\right)$ & $(1.152)$ & $(1.291)$ & $(0.154)$ & $(0.182)$ \\
\hline Supplier role of Industry & 0.495 & 0.428 & $0.675^{*}$ & $0.624 *$ \\
\hline$\left(S U P P_{i j}\right)$ & $(0.494)$ & $(0.482)$ & $(0.377)$ & $(0.364)$ \\
\hline Customer role of Partner & $-0.912 * * *$ & $-0.938 * * *$ & $-0.509 * * *$ & $-0.505 * * *$ \\
\hline$\left(C U S T_{i j}\right)$ & $(0.303)$ & $(0.293)$ & $(0.195)$ & $(0.194)$ \\
\hline Supplier role of Partner & $-2.174 * *$ & $-2.179 *$ & $-0.541 * *$ & $-0.503 * *$ \\
\hline$\left(S U P P_{j i}\right)$ & $(1.051)$ & $(1.154)$ & $(0.220)$ & $(0.229)$ \\
\hline Industry Size & & 0.025 & & 0.035 \\
\hline & & $(0.080)$ & & $(0.033)$ \\
\hline Partner Size & & -0.047 & & -0.013 \\
\hline & & $(0.031)$ & & $(0.011)$ \\
\hline Observations & 4,160 & 3,906 & 4,160 & 3,906 \\
\hline Adjusted $\mathrm{R}^{2}$ & 0.003 & 0.002 & 0.002 & 0.002 \\
\hline
\end{tabular}


Panel 3. The business linkage variables and the industry size (millions of firms) refer to year 2008

\begin{tabular}{|c|c|c|c|c|}
\hline & \multicolumn{2}{|c|}{ GARCH spillover } & \multicolumn{2}{|c|}{ ARCH spillover } \\
\hline & (1) & (2) & (3) & (4) \\
\hline $\begin{array}{l}\text { Customer role of Industry } \\
\left(C U S T_{j i}\right)\end{array}$ & $\begin{array}{c}1.446 \\
(1.193)\end{array}$ & $\begin{array}{c}1.377 \\
(1.379)\end{array}$ & $\begin{array}{l}0.296 * \\
(0.155)\end{array}$ & $\begin{array}{c}0.192 \\
(0.190)\end{array}$ \\
\hline $\begin{array}{l}\text { Supplier role of Industry } \\
\left(S U P P_{i j}\right)\end{array}$ & $\begin{array}{c}0.657 \\
(0.523)\end{array}$ & $\begin{array}{c}0.600 \\
(0.521)\end{array}$ & $\begin{array}{l}0.686 * * \\
(0.345)\end{array}$ & $\begin{array}{l}0.645^{*} \\
(0.340)\end{array}$ \\
\hline $\begin{array}{l}\text { Customer role of Partner } \\
\left(C U S T_{i j}\right)\end{array}$ & $\begin{array}{c}-0.944 * * * \\
(0.320)\end{array}$ & $\begin{array}{c}-1.013 * * * \\
(0.325)\end{array}$ & $\begin{array}{c}-0.528 * * * \\
(0.190)\end{array}$ & $\begin{array}{c}-0.546 * * * \\
(0.198)\end{array}$ \\
\hline $\begin{array}{l}\text { Supplier role of Partner } \\
\left(S U P P_{j i}\right)\end{array}$ & $\begin{array}{l}-2.157 * * \\
(0.970)\end{array}$ & $\begin{array}{c}-2.221 * * \\
(1.104)\end{array}$ & $\begin{array}{c}-0.540 * * * \\
(0.199)\end{array}$ & $\begin{array}{l}-0.516 * * \\
(0.216)\end{array}$ \\
\hline Industry Size & & $\begin{array}{c}0.024 \\
(0.081)\end{array}$ & & $\begin{array}{c}0.035 \\
(0.033)\end{array}$ \\
\hline Partner Size & & $\begin{array}{l}-0.036 \\
(0.031)\end{array}$ & & $\begin{array}{l}-0.010 \\
(0.011)\end{array}$ \\
\hline Observations & 4,160 & 3,906 & 4,160 & 3,906 \\
\hline Adjusted $\mathrm{R}^{2}$ & 0.003 & 0.002 & 0.003 & 0.002 \\
\hline
\end{tabular}

Panel 4. The business linkage variables and the industry size (millions of firms) refer to year 2009

\begin{tabular}{|c|c|c|c|c|}
\hline & \multicolumn{2}{|c|}{ GARCH spillover } & \multicolumn{2}{|c|}{ ARCH spillover } \\
\hline & (1) & (2) & (3) & (4) \\
\hline $\begin{array}{l}\text { Customer role of Industry } \\
\left(C U S T_{j i}\right)\end{array}$ & $\begin{array}{c}1.234 \\
(0.989)\end{array}$ & $\begin{array}{c}1.114 \\
(1.135)\end{array}$ & $\begin{array}{l}0.253 * \\
(0.146)\end{array}$ & $\begin{array}{c}0.141 \\
(0.180)\end{array}$ \\
\hline $\begin{array}{l}\text { Supplier role of Industry } \\
\left(S U P P_{i j}\right)\end{array}$ & $\begin{array}{c}0.688 \\
(0.593)\end{array}$ & $\begin{array}{c}0.606 \\
(0.579)\end{array}$ & $\begin{array}{l}0.741^{*} \\
(0.408)\end{array}$ & $\begin{array}{l}0.688^{*} \\
(0.396)\end{array}$ \\
\hline $\begin{array}{l}\text { Customer role of Partner } \\
\left(C U S T_{i j}\right)\end{array}$ & $\begin{array}{c}-0.911 * * * \\
(0.327)\end{array}$ & $\begin{array}{c}-0.993 * * * \\
(0.331)\end{array}$ & $\begin{array}{c}-0.527^{* *} \\
(0.207)\end{array}$ & $\begin{array}{c}-0.548 * * \\
(0.213)\end{array}$ \\
\hline $\begin{array}{l}\text { Supplier role of Partner } \\
\left(S U P P_{j i}\right)\end{array}$ & $\begin{array}{c}-2.139 * * \\
(1.005)\end{array}$ & $\begin{array}{l}-2.184 * \\
(1.135)\end{array}$ & $\begin{array}{c}-0.549 * * \\
(0.224)\end{array}$ & $\begin{array}{c}-0.522 * * \\
(0.243)\end{array}$ \\
\hline Industry Size & & $\begin{array}{c}0.032 \\
(0.083)\end{array}$ & & $\begin{array}{c}0.037 \\
(0.035)\end{array}$ \\
\hline Partner Size & & $\begin{array}{l}-0.024 \\
(0.034)\end{array}$ & & $\begin{array}{l}-0.007 \\
(0.012)\end{array}$ \\
\hline Observations & 4,160 & 3,906 & 4,160 & 3,906 \\
\hline Adjusted $\mathrm{R}^{2}$ & 0.002 & 0.002 & 0.002 & 0.002 \\
\hline
\end{tabular}


Panel 5. The business linkage variables and the industry size (millions of firms) refer to year 2010

\begin{tabular}{|c|c|c|c|c|}
\hline & \multicolumn{2}{|c|}{ GARCH spillover } & \multicolumn{2}{|c|}{ ARCH spillover } \\
\hline & $(1)$ & $(2)$ & (3) & (4) \\
\hline $\begin{array}{l}\text { Customer role of Industry } \\
\left(C U S T_{j i}\right)\end{array}$ & $\begin{array}{c}1.564 \\
(1.250)\end{array}$ & $\begin{array}{c}1.509 \\
(1.438)\end{array}$ & $\begin{array}{l}0.320 * \\
(0.164)\end{array}$ & $\begin{array}{c}0.219 \\
(0.198)\end{array}$ \\
\hline $\begin{array}{l}\text { Supplier role of Industry } \\
\left(S U P P_{i j}\right)\end{array}$ & $\begin{array}{c}0.594 \\
(0.539)\end{array}$ & $\begin{array}{c}0.554 \\
(0.534)\end{array}$ & $\begin{array}{l}0.765^{*} \\
(0.425)\end{array}$ & $\begin{array}{l}0.732 * \\
(0.420)\end{array}$ \\
\hline $\begin{array}{l}\text { Customer role of Partner } \\
\left(C U S T_{i j}\right)\end{array}$ & $\begin{array}{c}-0.885^{* * *} \\
(0.328)\end{array}$ & $\begin{array}{c}-0.977 * * * \\
(0.335)\end{array}$ & $\begin{array}{c}-0.572 * * \\
(0.231)\end{array}$ & $\begin{array}{c}-0.603 * * \\
(0.237)\end{array}$ \\
\hline $\begin{array}{l}\text { Supplier role of Partner } \\
\left(S U P P_{j i}\right)\end{array}$ & $\begin{array}{l}-2.216^{* *} \\
(1.029)\end{array}$ & $\begin{array}{l}-2.269 * \\
(1.161)\end{array}$ & $\begin{array}{c}-0.558 * * * \\
(0.213)\end{array}$ & $\begin{array}{c}-0.532 * * \\
(0.232)\end{array}$ \\
\hline Industry Size & & $\begin{array}{c}0.028 \\
(0.083)\end{array}$ & & $\begin{array}{c}0.035 \\
(0.034)\end{array}$ \\
\hline Partner Size & & $\begin{array}{l}-0.021 \\
(0.034)\end{array}$ & & $\begin{array}{l}-0.006 \\
(0.012)\end{array}$ \\
\hline Observations & 4,160 & 3,906 & 4,160 & 3,906 \\
\hline Adjusted $\mathrm{R}^{2}$ & 0.003 & 0.002 & 0.003 & 0.003 \\
\hline
\end{tabular}

Panel 6. The business linkage variables and the industry size (millions of firms) refer to year 2011

\begin{tabular}{|c|c|c|c|c|}
\hline & \multicolumn{2}{|c|}{ GARCH spillover } & \multicolumn{2}{|c|}{ ARCH spillover } \\
\hline & $(1)$ & (2) & (3) & (4) \\
\hline $\begin{array}{l}\text { Customer role of Industry } \\
\left(C U S T_{j i}\right)\end{array}$ & $\begin{array}{c}1.652 \\
(1.340)\end{array}$ & $\begin{array}{c}1.621 \\
(1.531)\end{array}$ & $\begin{array}{l}0.342 * * \\
(0.168)\end{array}$ & $\begin{array}{c}0.252 \\
(0.199)\end{array}$ \\
\hline $\begin{array}{l}\text { Supplier role of Industry } \\
\left(S U P P_{i j}\right)\end{array}$ & $\begin{array}{c}0.596 \\
(0.522)\end{array}$ & $\begin{array}{c}0.565 \\
(0.520)\end{array}$ & $\begin{array}{l}0.736 * \\
(0.398)\end{array}$ & $\begin{array}{l}0.709 * \\
(0.398)\end{array}$ \\
\hline $\begin{array}{l}\text { Customer role of Partner } \\
\left(C U S T_{i j}\right)\end{array}$ & $\begin{array}{c}-0.876^{* * *} \\
(0.333)\end{array}$ & $\begin{array}{c}-0.979 * * * \\
(0.346)\end{array}$ & $\begin{array}{c}-0.559 * * \\
(0.221)\end{array}$ & $\begin{array}{c}-0.589 * * * \\
(0.226)\end{array}$ \\
\hline $\begin{array}{l}\text { Supplier role of Partner } \\
\left(S U P P_{j i}\right)\end{array}$ & $\begin{array}{l}-2.201 * * \\
(0.989)\end{array}$ & $\begin{array}{c}-2.280 * * \\
(1.119)\end{array}$ & $\begin{array}{c}-0.549 * * * \\
(0.196)\end{array}$ & $\begin{array}{l}-0.532 * * \\
(0.217)\end{array}$ \\
\hline Industry Size & & $\begin{array}{c}0.027 \\
(0.084)\end{array}$ & & $\begin{array}{c}0.035 \\
(0.034)\end{array}$ \\
\hline Partner Size & & $\begin{array}{l}-0.018 \\
(0.035)\end{array}$ & & $\begin{array}{l}-0.006 \\
(0.012)\end{array}$ \\
\hline Observations & 4,160 & 3,906 & 4,160 & 3,906 \\
\hline Adjusted $\mathrm{R}^{2}$ & 0.003 & 0.002 & 0.003 & 0.003 \\
\hline
\end{tabular}


Panel 7. The business linkage variables and the industry size (millions of firms) refer to year 2013

\begin{tabular}{|c|c|c|c|c|}
\hline & \multicolumn{2}{|c|}{ GARCH spillover } & \multicolumn{2}{|c|}{ ARCH spillover } \\
\hline & $(1)$ & (2) & (3) & (4) \\
\hline $\begin{array}{l}\text { Customer role of Industry } \\
\left(C U S T_{j i}\right)\end{array}$ & $\begin{array}{c}1.627 \\
(1.327)\end{array}$ & $\begin{array}{c}1.602 \\
(1.525)\end{array}$ & $\begin{array}{l}0.329 * \\
(0.170)\end{array}$ & $\begin{array}{c}0.243 \\
(0.200)\end{array}$ \\
\hline $\begin{array}{l}\text { Supplier role of Industry } \\
\left(S U P P_{i j}\right)\end{array}$ & $\begin{array}{c}0.513 \\
(0.496)\end{array}$ & $\begin{array}{c}0.493 \\
(0.487)\end{array}$ & $\begin{array}{l}0.666^{*} \\
(0.359)\end{array}$ & $\begin{array}{l}0.636^{*} \\
(0.355)\end{array}$ \\
\hline $\begin{array}{l}\text { Customer role of Partner } \\
\left(C U S T_{i j}\right)\end{array}$ & $\begin{array}{c}-0.886 * * * \\
(0.335)\end{array}$ & $\begin{array}{c}-1.025 * * * \\
(0.352)\end{array}$ & $\begin{array}{c}-0.537 * * * \\
(0.205)\end{array}$ & $\begin{array}{c}-0.571 * * * \\
(0.208)\end{array}$ \\
\hline $\begin{array}{l}\text { Supplier role of Partner } \\
\left(S U P P_{j i}\right)\end{array}$ & $\begin{array}{c}-2.197 * * \\
(1.015)\end{array}$ & $\begin{array}{c}-2.296 * * \\
(1.151)\end{array}$ & $\begin{array}{c}-0.545^{* * *} \\
(0.201)\end{array}$ & $\begin{array}{c}-0.534 * * \\
(0.223)\end{array}$ \\
\hline Industry Size & & $\begin{array}{c}0.025 \\
(0.082)\end{array}$ & & $\begin{array}{c}0.034 \\
(0.034)\end{array}$ \\
\hline Partner Size & & $\begin{array}{l}-0.000 \\
(0.036)\end{array}$ & & $\begin{array}{l}-0.002 \\
(0.013)\end{array}$ \\
\hline Observations & 4,160 & 3,906 & 4,160 & 3,906 \\
\hline Adjusted $\mathrm{R}^{2}$ & 0.003 & 0.002 & 0.003 & 0.002 \\
\hline
\end{tabular}


Panel 8. The business linkages variables constructed using the 2012 Input-Output Benchmark

\begin{tabular}{|c|c|c|c|c|c|c|c|c|}
\hline & \multicolumn{4}{|c|}{ GARCH spillover } & \multicolumn{4}{|c|}{ ARCH spillover } \\
\hline & (1) & (2) & (3) & (4) & (5) & $(6)$ & (7) & $(8)$ \\
\hline Customer role of Industry & 1.579 & 3.345 & 3.504 & 2.965 & $0.326^{*}$ & 0.414 & 0.511 & 0.333 \\
\hline$\left(C U S T_{j i}\right)$ & $(1.319)$ & $(2.986)$ & $(2.928)$ & $(3.001)$ & $(0.169)$ & $(0.347)$ & $(0.325)$ & $(0.345)$ \\
\hline Supplier role of Industry & 0.603 & 0.783 & 0.831 & 0.446 & $0.689 *$ & $1.178 * * *$ & $1.230 * * *$ & $1.098 * * *$ \\
\hline$\left(S U P P_{i j}\right)$ & $(0.536)$ & $(0.804)$ & $(0.818)$ & $(0.782)$ & $(0.370)$ & $(0.414)$ & $(0.439)$ & $(0.396)$ \\
\hline Customer role of Partner & $-0.910 * * *$ & $-1.553 * * *$ & $-1.622 * *$ & $-0.999 *$ & $-0.533 * * *$ & $-0.970 * * *$ & $-1.033 * * *$ & $-0.834 * * *$ \\
\hline$\left(C U S T_{i j}\right)$ & $(0.342)$ & $(0.587)$ & $(0.681)$ & $(0.592)$ & $(0.207)$ & $(0.329)$ & $(0.370)$ & $(0.319)$ \\
\hline Supplier role of Partner & $-2.168 * *$ & $-4.281 * * *$ & $-4.562 * * *$ & $-3.989 * * *$ & $-0.544 * * *$ & $-0.956 * * *$ & $-1.069 * * *$ & $-0.890 * * *$ \\
\hline$\left(S U P P_{j i}\right)$ & $(0.998)$ & $(1.304)$ & $(1.316)$ & $(1.322)$ & $(0.202)$ & $(0.194)$ & $(0.225)$ & $(0.197)$ \\
\hline \multirow[t]{2}{*}{ Industry Size } & & 0.069 & & 0.115 & & 0.047 & & 0.044 \\
\hline & & $(0.117)$ & & $(0.140)$ & & $(0.048)$ & & $(0.044)$ \\
\hline \multirow[t]{2}{*}{ Partner Size } & & 0.055 & & $-0.304 * * *$ & & 0.005 & & $-0.092 * * *$ \\
\hline & & $(0.050)$ & & $(0.052)$ & & $(0.017)$ & & $(0.016)$ \\
\hline \multirow[t]{2}{*}{ Industry Concentration } & & & 0.030 & 0.063 & & & -0.025 & -0.012 \\
\hline & & & $(0.069)$ & $(0.088)$ & & & $(0.034)$ & $(0.030)$ \\
\hline \multirow[t]{2}{*}{ Partner Concentration } & & & $-0.602 * * *$ & $-0.690 * * *$ & & & $-0.161 * * *$ & $-0.188^{* * *}$ \\
\hline & & & $(0.080)$ & $(0.087)$ & & & $(0.031)$ & $(0.033)$ \\
\hline Observations & 4,160 & 3,080 & 3,080 & 3,080 & 4,160 & 3,080 & 3,080 & 3,080 \\
\hline Adjusted $\mathrm{R}^{2}$ & 0.003 & 0.006 & 0.024 & 0.026 & 0.003 & 0.005 & 0.013 & 0.014 \\
\hline
\end{tabular}


Panel 9. Business linkages constructed using the average values of the IO Tables from 2005-2013

\begin{tabular}{|c|c|c|c|c|c|c|c|c|}
\hline & \multicolumn{4}{|c|}{ GARCH spillover } & \multicolumn{4}{|c|}{ ARCH spillover } \\
\hline & $(1)$ & $(2)$ & $(3)$ & $(4)$ & $(5)$ & $(6)$ & $(7)$ & $(8)$ \\
\hline Customer role of Industry & 1.503 & 1.420 & 3.631 & 3.077 & $0.301 *$ & 0.192 & $0.511^{*}$ & 0.345 \\
\hline$\left(C U S T_{j i}\right)$ & $(1.227)$ & $(1.408)$ & $(2.800)$ & $(2.844)$ & $(0.162)$ & $(0.195)$ & $(0.307)$ & $(0.324)$ \\
\hline Supplier role of Industry & 0.589 & 0.541 & 0.783 & 0.389 & $0.711^{*}$ & $0.671 *$ & $1.314 * * *$ & $1.184 * * *$ \\
\hline$\left(S U P P_{i j}\right)$ & $(0.536)$ & $(0.529)$ & $(0.859)$ & $(0.833)$ & $(0.387)$ & $(0.379)$ & $(0.457)$ & $(0.411)$ \\
\hline Customer role of Partner & $-0.925 * * *$ & $-1.015^{* * *}$ & $-1.626 * *$ & $-1.024 *$ & $-0.544 * * *$ & $-0.566 * * *$ & $-1.063 * * *$ & $-0.886^{* * *}$ \\
\hline$\left(C U S T_{i j}\right)$ & $(0.331)$ & $(0.331)$ & $(0.682)$ & $(0.590)$ & $(0.208)$ & $(0.211)$ & $(0.385)$ & $(0.332)$ \\
\hline Supplier role of Partner & $-2.217 * *$ & $-2.269 *$ & $-5.067 * * *$ & $-4.394 * * *$ & $-0.553 * *$ & $-0.527 * *$ & $-1.162 * * *$ & $-0.974 * * *$ \\
\hline$\left(S U P P_{j i}\right)$ & $(1.047)$ & $(1.178)$ & $(1.369)$ & $(1.363)$ & $(0.216)$ & $(0.234)$ & $(0.227)$ & $(0.199)$ \\
\hline \multirow[t]{2}{*}{ Industry Size } & & 0.025 & & 0.105 & & 0.035 & & 0.042 \\
\hline & & $(0.082)$ & & $(0.143)$ & & $(0.034)$ & & $(0.045)$ \\
\hline \multirow[t]{2}{*}{ Partner Size } & & -0.028 & & $-0.334 * * *$ & & -0.008 & & $-0.089 * * *$ \\
\hline & & $(0.033)$ & & $(0.052)$ & & $(0.012)$ & & $(0.015)$ \\
\hline \multirow[t]{2}{*}{ Industry Concentration } & & & -0.003 & 0.028 & & & -0.031 & -0.019 \\
\hline & & & $(0.069)$ & $(0.087)$ & & & $(0.034)$ & $(0.029)$ \\
\hline \multirow[t]{2}{*}{ Partner Concentration } & & & $-0.628 * * *$ & $-0.729 * * *$ & & & $-0.149 * * *$ & $-0.176^{* * *}$ \\
\hline & & & $(0.083)$ & $(0.090)$ & & & $(0.032)$ & $(0.034)$ \\
\hline Observations & 4,160 & 3,906 & 3,080 & 3,080 & 4,160 & 3,906 & 3,080 & 3,080 \\
\hline Adjusted $\mathrm{R}^{2}$ & 0.003 & 0.002 & 0.025 & 0.027 & 0.003 & 0.002 & 0.012 & 0.012 \\
\hline
\end{tabular}

Note: The business linkage measures and industry size (millions of firms) are the respective average values over the 2005 -2013 sample period. The industry concentration ratios refer to year 2007.

This table reports cross-sectional estimated coefficients and bootstrapped standard errors (in parentheses). The dependent variables are the GARCH spillover and the ARCH spillover coefficients obtained from the multivariate GARCH model (equations (1)-(6)) using daily returns over the period 1 January 2005 - 31 December 2013. The relation between the two volatility spillover coefficients and the business linkage variables are specified in Eqs. (8) and (9). *,** and *** denote the $10 \%, 5 \%$ and $1 \%$ significance levels, respectively. Data for industry size is available annually; the concentration ratio is published every 5 years at the same time as the benchmark IO tables. Details of the data used to construct the business linkage variables and industry size is stated in the heading of each panel. 
Table E.2. The impact of business linkages on volatility spillover for non-financial industries

\begin{tabular}{|c|c|c|c|c|c|c|c|c|}
\hline & \multicolumn{4}{|c|}{ GARCH spillover } & \multicolumn{4}{|c|}{ ARCH spillover } \\
\hline & $(1)$ & $(2)$ & (3) & $(4)$ & $(5)$ & $(6)$ & $(7)$ & $(8)$ \\
\hline $\begin{array}{l}\text { Customer role of Industry } \\
\left(C U S T_{j i}\right)\end{array}$ & $\begin{array}{c}1.838 \\
(1.307)\end{array}$ & $\begin{array}{c}1.862 \\
(1.512)\end{array}$ & $\begin{array}{c}4.210 \\
(3.501)\end{array}$ & $\begin{array}{c}3.557 \\
(3.549)\end{array}$ & $\begin{array}{l}0.359 * * \\
(0.166)\end{array}$ & $\begin{array}{c}0.256 \\
(0.203)\end{array}$ & $\begin{array}{l}0.646^{*} \\
(0.386)\end{array}$ & $\begin{array}{c}0.444 \\
(0.402)\end{array}$ \\
\hline $\begin{array}{l}\text { Supplier role of Industry } \\
\left(S U P P_{i j}\right)\end{array}$ & $\begin{array}{l}1.455^{*} \\
(0.784)\end{array}$ & $\begin{array}{l}1.398^{*} \\
(0.823)\end{array}$ & $\begin{array}{c}1.760 \\
(1.276)\end{array}$ & $\begin{array}{c}1.183 \\
(1.228)\end{array}$ & $\begin{array}{c}1.037 * * * \\
(0.347)\end{array}$ & $\begin{array}{c}0.968 * * * \\
(0.350)\end{array}$ & $\begin{array}{l}1.279 * * \\
(0.533)\end{array}$ & $\begin{array}{l}1.086 * * \\
(0.455)\end{array}$ \\
\hline $\begin{array}{l}\text { Customer role of Partner } \\
\left(C U S T_{i j}\right)\end{array}$ & $\begin{array}{c}-1.172 * * * \\
(0.399)\end{array}$ & $\begin{array}{c}-1.275 * * * \\
(0.453)\end{array}$ & $\begin{array}{l}-2.152 * * \\
(1.033)\end{array}$ & $\begin{array}{l}-1.444 * \\
(0.868)\end{array}$ & $\begin{array}{c}-0.614 * * * \\
(0.197)\end{array}$ & $\begin{array}{c}-0.612^{* * *} \\
(0.214)\end{array}$ & $\begin{array}{c}-1.068 * * \\
(0.483)\end{array}$ & $\begin{array}{c}-0.859 * * \\
(0.399)\end{array}$ \\
\hline $\begin{array}{l}\text { Supplier role of Partner } \\
\left(S U P P_{j i}\right)\end{array}$ & $\begin{array}{c}-3.621 * * * \\
(1.032)\end{array}$ & $\begin{array}{c}-3.952 * * * \\
(1.106)\end{array}$ & $\begin{array}{c}-5.607 * * * \\
(1.853)\end{array}$ & $\begin{array}{c}-4.801 * * * \\
(1.844)\end{array}$ & $\begin{array}{c}-0.811 * * * \\
(0.160)\end{array}$ & $\begin{array}{c}-0.800^{* * *} \\
(0.164)\end{array}$ & $\begin{array}{c}-1.191 * * * \\
(0.288)\end{array}$ & $\begin{array}{c}-0.967 * * * \\
(0.256)\end{array}$ \\
\hline Industry Size & & $\begin{array}{c}0.009 \\
(0.082)\end{array}$ & & $\begin{array}{c}0.134 \\
(0.156)\end{array}$ & & $\begin{array}{c}0.035 \\
(0.035)\end{array}$ & & $\begin{array}{c}0.063 \\
(0.049)\end{array}$ \\
\hline Partner Size & & $\begin{array}{l}-0.024 \\
(0.032)\end{array}$ & & $\begin{array}{c}-0.377 * * * \\
(0.061)\end{array}$ & & $\begin{array}{l}-0.012 \\
(0.010)\end{array}$ & & $\begin{array}{c}-0.091 * * * \\
(0.017)\end{array}$ \\
\hline Industry Concentration & & & $\begin{array}{c}0.024 \\
(0.082)\end{array}$ & $\begin{array}{c}0.062 \\
(0.099)\end{array}$ & & & $\begin{array}{c}-0.034 \\
(0.040)\end{array}$ & $\begin{array}{l}-0.015 \\
(0.035)\end{array}$ \\
\hline Partner Concentration & & & $\begin{array}{c}-0.771 * * * \\
(0.108)\end{array}$ & $\begin{array}{c}-0.900 * * * \\
(0.119)\end{array}$ & & & $\begin{array}{c}-0.150 * * * \\
(0.041)\end{array}$ & $\begin{array}{c}-0.180 \text { *** } \\
(0.044)\end{array}$ \\
\hline Observations & 3,422 & 3,192 & 2,500 & 2,500 & 3,422 & 3,192 & 2,500 & 2,500 \\
\hline Adjusted $\mathrm{R}^{2}$ & 0.004 & 0.004 & 0.026 & 0.029 & 0.003 & 0.003 & 0.009 & 0.010 \\
\hline
\end{tabular}

This table reports cross-sectional estimated coefficients and bootstrapped standard errors (in parentheses). The dependent variables are the GARCH spillover and the ARCH spillover coefficients obtained from the multivariate GARCH model (Eqs. (1)-(6)) using daily returns over the period 1 January 2005 - 31 December 2013 . The sample includes only non-financial industry pairs. The relation between the two volatility spillover coefficients and the business linkage variables are specified in Eqs. (8) and (9). The business linkage variables, industry size (millions of firms) and the concentration ratios refer to year $2007 . * * *$ and $* * *$ denote the $10 \%, 5 \%$ and $1 \%$ significance levels, respectively. 
Table E.3. The impact of business linkages on volatility spillover for closely related industries

\begin{tabular}{|c|c|c|c|c|c|c|c|c|}
\hline & \multicolumn{4}{|c|}{ GARCH spillover } & \multicolumn{4}{|c|}{ ARCH spillover } \\
\hline & $(1)$ & $(2)$ & (3) & $(4)$ & $(5)$ & $(6)$ & $(7)$ & $(8)$ \\
\hline Customer role of Industry & 1.233 & 0.838 & 3.421 & 2.611 & 0.182 & -0.043 & 0.387 & 0.033 \\
\hline$\left(C U S T_{j i}\right)$ & (1.066) & $(1.243)$ & $(2.742)$ & $(2.770)$ & $(0.181)$ & $(0.248)$ & $(0.318)$ & $(0.391)$ \\
\hline Supplier role of Industry & 0.383 & 0.122 & 0.433 & -0.263 & 0.406 & 0.297 & $0.758 * * *$ & $0.439 *$ \\
\hline$\left(S U P P_{i j}\right)$ & $(0.431)$ & $(0.382)$ & $(0.716)$ & $(0.659)$ & $(0.252)$ & $(0.211)$ & $(0.270)$ & $(0.252)$ \\
\hline Customer role of Partner & $-0.842 * * *$ & $-0.666^{* *}$ & $-1.365^{* *}$ & -0.595 & $-0.538 * * *$ & $-0.490 * * *$ & $-1.073^{* * *}$ & $-0.729 * *$ \\
\hline$\left(C U S T_{i j}\right)$ & $(0.310)$ & $(0.321)$ & $(0.674)$ & $(0.559)$ & $(0.191)$ & $(0.188)$ & $(0.407)$ & $(0.286)$ \\
\hline Supplier role of Partner & $-1.761 *$ & -1.612 & $-4.220 * * *$ & $-3.392 * * *$ & $-0.667 * *$ & $-0.580 *$ & $-1.471 * * *$ & $-1.117 * * *$ \\
\hline$\left(S U P P_{j i}\right)$ & $(1.003)$ & $(1.005)$ & (1.309) & $(1.277)$ & $(0.339)$ & $(0.322)$ & $(0.384)$ & $(0.287)$ \\
\hline \multirow[t]{2}{*}{ Industry Size } & & 0.161 & & $0.238 *$ & & 0.074 & & $0.127 *$ \\
\hline & & $(0.099)$ & & $(0.137)$ & & $(0.058)$ & & $(0.075)$ \\
\hline \multirow[t]{2}{*}{ Partner Size } & & $-0.128 * * *$ & & $-0.483 * * *$ & & $-0.045^{* *}$ & & $-0.191 * * *$ \\
\hline & & $(0.039)$ & & $(0.103)$ & & $(0.020)$ & & $(0.054)$ \\
\hline \multirow[t]{2}{*}{ Industry Concentration } & & & $-0.188 *$ & -0.096 & & & -0.030 & 0.020 \\
\hline & & & $(0.102)$ & $(0.092)$ & & & $(0.094)$ & $(0.083)$ \\
\hline \multirow[t]{2}{*}{ Partner Concentration } & & & $-0.553 * * *$ & $-0.749 * * *$ & & & $-0.220 * * *$ & $-0.297 * * *$ \\
\hline & & & $(0.127)$ & $(0.156)$ & & & $(0.079)$ & $(0.096)$ \\
\hline Observations & 1,504 & 1,430 & 1,158 & 1,158 & 1,504 & 1,430 & 1,158 & 1,158 \\
\hline Adjusted $\mathrm{R}^{2}$ & 0.006 & 0.008 & 0.031 & 0.040 & 0.002 & 0.002 & 0.009 & 0.012 \\
\hline
\end{tabular}

This table reports cross-sectional estimated coefficients and bootstrapped standard errors (in parentheses). The dependent variables are the GARCH spillover and the ARCH spillover coefficients obtained from the multivariate GARCH model (Eqs. (1)-(6)) using daily returns over the period 1 January 2005 - 31 December 2013 . The sample includes only industry pairs for which at least one of the four trading variables meets the minimum $1 \%$ threshold in Table 3 . The relation between the two volatility spillover coefficients and the business linkage variables are specified in Eqs. (8) and (9). The business linkage variables, industry size (millions of firms) and the concentration ratios refer to year 2007. *,** and $* * *$ denote the $10 \%, 5 \%$ and $1 \%$ significance levels, respectively. 